\title{
Deep brain stimulation in parkinsonian patients - ethical evaluation of cognitive, affective, and behavioral sequelae
}

\author{
Müller, S ; Christen, M
}

\begin{abstract}
Deep brain stimulation (DBS) of the subthalamic nucleus (STN) is an important therapeutic advancement for the treatment of Parkinson's disease (PD). Its beneficial effects on motor functions are well established, but its cognitive, affective, and behavioral sequelae come increasingly into the focus of the medical and ethical discussion. In order to evaluate whether these side effects may counteract the beneficial effects of STN DBS on the patient's quality of life, we classify them along the dimensions "measurement complexity" and "weighted life-impact." Based on this analysis, we discuss their ethical impact and propose guidelines for the clinical setting of STN DBS.
\end{abstract}

DOI: https://doi.org/10.1080/21507740.2010.533151

Posted at the Zurich Open Repository and Archive, University of Zurich ZORA URL: https://doi.org/10.5167/uzh-55241

Journal Article

Accepted Version

Originally published at:

Müller, S; Christen, M (2011). Deep brain stimulation in parkinsonian patients - ethical evaluation of cognitive, affective, and behavioral sequelae. AJOB Neuroscience, 2(1):3-13.

DOI: https://doi.org/10.1080/21507740.2010.533151 


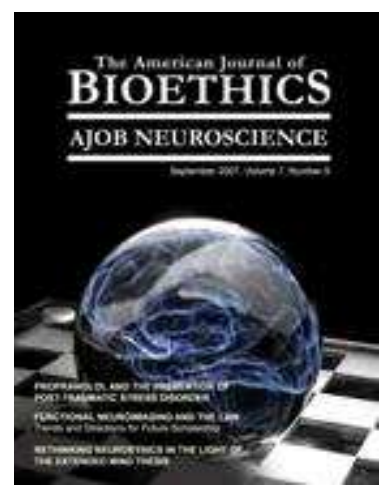

\section{Dealing with Side Effects of Deep Brain Stimulation: Lessons Learned from Stimulating the STN}

\begin{tabular}{|r|l|}
\hline Journal: & AJOB Neuroscience Journal \\
\hline Manuscript ID: & UABN-2011-0047.R1 \\
\hline Manuscript Type: & Target Article \\
\hline Keywords: & Deep Brain Stimulation, psychiatry, Harm, Neuroethics, Neurosurgery \\
\hline \multicolumn{2}{|c}{} \\
\hline
\end{tabular}

\section{SCHOLARONE Manuscripts}




\begin{abstract}
Deep brain stimulation (DBS) is increasingly investigated as a therapy for psychiatric disorders. In the ethical evaluation of this novel approach, incidence and impact of side effects (SE) play a key role. In our contribution, we analyze the discussion on SE of DBS of the subthalamic nucleus (STN) - a standard therapy for movement disorders like Parkinson's disease (PD) - based on 66 case reports, 69 review papers, and 347 outcome studies from 1993 to 2009 . We show how the DBS community increasingly acknowledged the complexity of STN-DBS side effects. Then we discuss the issue of study quality and the methods used to assess SE. We note that some side effects are subject of conflicting evaluations by the different stakeholders involved. This complicates the ethical controversy inherent in any novel treatments for diseases that involve psychiatric aspects. We delineate how the lessons from STN-DBS could guide future DBS applications in the field of psychiatry.
\end{abstract}

Key words: Deep brain stimulation, psychiatry, Parkinson's disease, subthalamic nucleus, side effects, neuroethics.

\title{
Introduction
}

Since the advent of medicine, the maxim "do not harm your patient" forms the core of the ethos for physicians. This is reflected in the principle of nonmaleficience as one of the four principles of biomedical ethics (Beauchamp \& Childress 2009). Nevertheless, it is broadly acknowledged that harmful side effects (SE) of therapies have to be weighed up against their beneficial effects. The deliberation of harms and benefits becomes more difficult if side effects of novel therapeutic approaches have to be considered, of which nature, extent, and incidence are not yet known.

Deep brain stimulation (DBS) is an example for a novel therapeutic approach. Its roots go back to the early 1950s (Hariz et al. 2010), and it emerged in its current form in the 1980s as an alternative for ablative surgery in movement disorders and an experimental therapy in chronic pain (Siegfried \& Blons 1997). DBS became an established therapy for Parkinson's disease (PD) and other movement disorders in the last decade (Benabid et al. 2009). Side effects have been discussed since the advent of DBS, but the sensibility for them and the appreciation of their complexity is increasing. This also reflects the maturation of the therapy.

The term 'side effect' does not provide per se an ethical orientation how to deal with a specific therapy. Therefore terms like 'adverse events' or 'sequelae' (adverse events that count as long-term negative consequences) should be avoided as long as the negative evaluation of the side effect is not clear. For evaluating particular side effects, they can be classified along the two dimensions predictability and evaluation (Table 1).

\section{INSERT TABLE 1}

Table 1: $\quad$ Ethical requirements depending on the predictability and the evaluation of the side effects of a therapy. 
As Table 1 shows, only one type of side effects (predictable and clearly outweighing the benefits) bears the clear "ethical message" that the therapy should not be applied or that research on this therapy should be stopped. Thus, the determination of what counts as an adverse event involves both a measurement problem and an evaluation problem which can be entangled in the process of developing the therapy (Müller \& Christen 2011). DBS for PD patients is a paradigmatic example for outlining that problem, since first the predictability of side effects for individual patients is difficult, second the evaluation of some side effects differs significantly between patients, their relatives and physicians (Müller \& Christen 2011), and third both the disease (Kulisevsky et al. 2008) and alternative therapeutic approaches (medication or surgery, see Voon et al. 2006 and Olanow 2002) may involve similar effects as DBS.

The following investigation is based on a comprehensive literature analysis of the research literature on DBS in the nucleus subthalamicus (STN), the preferred target for DBS in PD. This analysis covers 66 case reports, 69 review papers, and 347 outcome studies from 1993 to 2009 that emerged from an extensive search in the following databases: CPCI-S, Embase, Francis, Medline, PsychINFO and SCI-expanded (the reference lists are available as supporting online material).

As the STN is part of various thalamo-cortical circuits (Marani et al 2008), the relatively high incidence of cognitive and affective side effects after STN DBS compared to other DBS targets is not surprising (Hariz et al. 2008). The way the DBS community dealt with this issue is thus a paradigmatic case for analyzing SE measurement and evaluation in the course of the establishment of novel therapies. Understanding this process may support the ethical analysis of the current application of DBS to a variety of psychiatric disorders (for an overview about psychiatric DBS see Krack et al. 2010).

\section{The complexity of adverse events}

Since the early 1990s, the STN was investigated as a potential DBS target both in animal and clinical studies. In 1993, the first case was published in a French journal (Pollak et al. 1993). Several case reports and outcome studies followed, and since the late 1990s the number of publications on STN-DBS has increased steadily (Müller \& Christen 2011). The number of STN-DBS related issues discussed in the literature has grown rapidly, whereas a bibliometric investigation demonstrated that case reports spearhead the transdisciplinary communication about DBS (Christen \& Müller 2011).

To handle the complexity of issues that are discussed in our literature body of 482 STN-DBS publications, we have sorted them into 18 issue classes (Table 2). For each class, we have evaluated all tests used in the outcome literature to measure the respective phenomena and the wording used to describe the corresponding SE. Note that not each issue class is directly related to SE. This is true especially for studies on the neuronal basis of DBS effects (usually investigated by PET) or about the cost-effectiveness of DBS. Furthermore, the boundaries between some issue classes are less clear and required predefinitions. For example, we have classified studies about language fluency as 'cognitive' (in accordance with the current neuropsychological understanding).

Each publication (case report, review, outcome study) was attributed to one or several issue classes with regard to the topics discussed and the methods used. Thereby we did not take into account possible causal relations between certain issues. For example, many issues have an 
impact on the quality of life (Q). Nevertheless, a study whose, e.g., primary focus was insomnia was only classified as 'I', not as 'Q'. For analyzing the time course of the publication praxis, it was necessary to build bigger groups. Therefore we have grouped the 18 issue classes into four groups as follows:

1. Group: Understanding therapeutic effects: F, M, V

2. Group: Medical and technical intervention issues: $\mathrm{O}, \mathrm{P}, \mathrm{T}$

3. Group: Main affective, behavioral and cognitive side effects of DBS: B, C, D, L, Q

4. Group: Other issues: A, E, I, K, N, S, W

\section{INSERT TABLE 2}

Table 2: $\quad$ Issue classes of therapeutic effects and side effects present in the STN-DBS literature. Only selected examples of side effects using the wording found in the publications are displayed.

The histogram in Fig. 1 shows the time-course of the different groups of issues in the DBS literature. The absolute numbers of publications per year belonging to one of the four issue groups are displayed for the years 1993 to 2009. The analysis reveals that - after the first, pioneering years with very few studies - issues on main affective, behavioral and cognitive side effects quickly appeared in the literature and became the dominant group since 2003. This finding is corroborated by an analysis of DBS posters presented at conferences (Christen \& Müller 2011). Although one has to take into account that this analysis is not sensible for the valuation of these effects (i.e. whether they are considered to be unproblematic or not), this finding somehow contrasts with several statements in the literature, that the DBS community would often ignore the neurobehavioral consequences of the therapy (e.g., Burn \& Tröster 2004).

\section{INSERT FIGURE 1}

Figure 1: The histogram displays the total number of issues (compare with Table 2) addressed in the publications about STN-DBS (case reports, reviews, and outcome studies) pooled in four groups (Group 1: F, M, V / Group 2: O, P, T / Group 3: B, C, D, L, Q / Group 4: A, E, I, K, N, $\mathrm{S}$, W; see text).

\section{Quality of STN-DBS studies}

The sensibility for novel side effects in the process of maturation of a novel therapy is a critical issue - and we may say that the DBS community has passed this test successfully. Another issue is the quality of the studies. Although it is well-known that novel therapies start with isolated case studies that usually lack quality criteria like randomization or blinding, at some point the urge for better studies is raised. DBS did not deviate from this development path, and various authors have discussed the issue of study quality (e.g. Woods et al. 2006) and proposed standards for improving study quality (e.g. Morrison et al. 2000). We investigated the study quality for all outcome studies that involved at least one issue of group 3 (i.e.: B, C, D, L, or Q). For that, we expanded the criteria for level of evidence assignment proposed by Martinez-Martin \& Deuschl (2007) using a rating system that involves several aspects being considered as relevant for study quality (e.g. regarding follow-up time) by the DBS community. ${ }^{\mathrm{i}}$

As Fig. 2.a demonstrates, the quality range of the studies is broad. Somewhat surprising is the fact that the mean quality of the outcome studies did not increase significantly since 2000 
(Fig. 2.b; earlier studies where not taken into account due to their low numbers). Although the absolute number of high quality studies of group 3 has increased, they are shrouded by the also increasing number of outcome studies of poor quality.

This absent increase of the average study quality is not per se problematic, as long as the community is able to differ between good and poor studies. To investigate whether this is the case, we calculated a citation coefficient based on DBS review papers about the outcome studies of group 3. ${ }^{\text {ii }}$ Then we performed a correlation analysis of the relationship of this citation coefficient and the quality rating for each study. The result is a (weak) positive correlation of the citation coefficient with the quality rating (Pearson's correlation coefficient: $0.29)$. That means that high quality papers tend to be cited more often in the reviews. This can be interpreted as a hint for a higher appreciation of high quality studies of group 3 by the DBS community.

\title{
INSERT FIGURE 2
}

\begin{abstract}
Figure 2: $\quad$ (a) Quality rating distribution of the outcome studies of group 3, (b) time-course of the mean quality rating of outcome studies (group 3), (c) correlation between the citation coefficient of studies (which reflects the appreciation of papers by the authors of reviews) with the quality rating of the studies. The chart also includes the linear approximation of the correlation.
\end{abstract}

\section{Measuring Adverse Events}

After investigating the attention for side effects of group 3 and the quality of the studies investigating them, we investigated a third issue: To what extent do the studies capture "relevant" side effects, i.e. those reflecting serious ethical issues (see Table 1). This point requires a closer look to the methods and tests used in the outcome studies. We listed all tests used in the 347 outcome studies and attributed them to one of the 18 issue groups. Far most of the tests were assigned to one of the five issue classes B, C, D, L, and Q (group 3), whereas the internal distribution is very uneven. Fig. 3.a demonstrates that more than half of all methods applied are tests regarding cognitive issues. Also the number of uses of the tests themselves is remarkably uneven. Only very few tests are used regularly. Furthermore, the probability that a test is used in a study for neuropsychological outcome assessment does not correspond completely to the four standards proposed in the literature (Defer et al. 1999, Saint-Cyr et al. 2000, Morrison et al. 2000, Pillon 2002). For example, the Hopkins Verbal Learning Test and the Odd Man Out Test, both recommended in all four standards, are comparably rarely used. This may indicate a learning effect by the community, as better tests than the ones initially recommended are available that measure similar constructs.

For the ethical evaluation it is of particular interest which perspectives are represented in the tests, as conflicting evaluations of side effects often result from different perspectives of stakeholders. For analyzing this point, we have classified all tests as follows:

I) Test scores that result from the evaluation of the patient's performance by a trained evaluator

II) Test scores that result from a self-assessment of the patient

III) Test scores that result from an interrogation etc. from closely related persons of the patient (family members, caregivers)

In order to avoid biases due to low quality studies, we have only investigated those studies that achieved a quality rating of at least 5 (see footnote 1,182 studies). We have counted the 


\title{
INSERT FIGURE 3
}

number of different tests, the number of test executions (i.e. in how many studies the test was used) and the number of patients that have been tested by these methods. The cumulative numbers for the three classes I, II and III are displayed in Fig. 3.b.

\begin{abstract}
Figure 3: $\quad$ a: Number of tests per issue class (B: behavioral, C: cognitive, D: depression and other mood issues, L: language, Q: quality of life). b: Number of different tests (first bar in each group), of accumulated test executions (middle bar) and total number of patients tested (left bar, right scale) with methods of either class I (test scores generated by evaluator), II (self-assessment of patient) or III (test scores emerge from persons affiliated to the patient).
\end{abstract}

We see a clear dominance of category I tests, whereas the usage of category III tests is basically nonexistent. Thus, the perspective on side effects is very biased in the DBS literature. This finding might explain the "satisfaction gap" between the physician's and the patient's expectation that is discussed in the literature (Agid et al 2006).

\section{The Ethics of Adverse Events: Conclusions and Recommendations for Psychiatric DBS}

What is the impact of this in-depth analysis of the literature about side effects of STN-DBS for the ethical debate about the application of DBS in psychiatry? Compared to many somatic diseases, harm-benefit-assessments for psychiatric therapies are complicated by at least three problems: First, for most psychiatric disorders no clear correlation with a specific neurological dysfunction is proven. Second, many interventions affect various neuronal mechanisms, e.g., SSRI have effects not only on the serotonin metabolism, but also on the neurogenesis in the hippocampus (Santarelli et al. 2003). Third, the evaluation of both the disease and the beneficial and negative therapy effects depend much stronger on subjective evaluations than this is valid for the somatic medicine. For example, neither patients nor their relatives nor their physicians would doubt that toothache is painful, whereas hypomania is evaluated differently by different stakeholders (see e.g. the examples in Krug et al. 2010). 'Clear-cut' cases (predictable side effects that clearly outbalance therapeutic effects) are probably rather rare in psychiatric diseases.

This is important, since the introduction of DBS to psychiatry is driven also by the expectation that it will improve the understanding of the causes of these diseases and that it will be a causal therapy. Already the usage of DBS for the treatment of movement disorders was accompanied by the narrative that DBS is more precise than its alternatives, completely reversible, and individually scalable. Although this is to a large extent true, the problems of measuring and evaluating side effects do not vanish. In the contrary, our analysis revealed that the availability of a more precise tool triggered research on the mechanisms behind the effects of DBS on cognitive functions, mood, and behavior and thus tends to increase the spectrum of potential SE to look at. If DBS will play an important role in psychiatry, we cannot expect that the SE spectrum will become smaller compared to that implicated by the alternatives.

However, we have found a well-developed sensibility for side effects in the DBS community. Nevertheless, the side effects are not yet measured and evaluated sufficiently. Our analysis reveals that the majority of methods used investigate subtle cognitive changes which may be statistically significant but whose relevance for the patients is unclear. Only a minority of investigations focus on the self-assessment of the patients, and even less on the assessments of their caregivers. This methodological bias implies blindness for certain side effects. We expect that this problem will be aggravated if DBS is used to treat psychiatric disorders as 
depression or addiction, since interpersonal relationships play a crucial role in overcoming these disorders.

Finally, the quality of studies that promote the extended use of DBS gives cause for concern, although we note that our rating system does not take into account that the requirements for quality may differ between studies if they addressed different types of outcomes, such that not all quality items are required for a specific study. After all, progress is recognizable and the community is somewhat able to discriminate between good and bad studies, yet it has not managed to cut down the continuous generation of low quality contributions.

In summary, the ethical evaluation of side effects of STN-DBS must not abstract from the measurement and evaluation problems that constitute the definition of what counts as a 'side effect'. The role of ethicists is not only to safeguard against the "bad effects" of therapies. They should also point at blind spots in clinical studies and widen the perspective on all sorts of effects of new therapies.

This research has been supported by the Swiss Academy of Medical Sciences (Käthe-ZinggSchwichtenberg-Fonds) and by the Federal Ministry of Education and Research, Germany (project no. 01 GP 0804).

\section{References}

Agid, Y., Schüpbach, M., Gargiulo, M., Mallet, L., Houeto, J.L., Behar, C., Maltête, D., Mesnage, V., and Welter, M.L. 2006. Neurosurgery in Parkinson's disease: the doctor is happy, the patient less so? J Neural Transm Suppl. (70): 409-14.

Beauchamp, T. L., and Childress, J. F. 2009. The Principles of Biomedical Ethics, 6. ed., Oxford: Oxford University Press.

Benabid, A. L., Chabardes, S., Mitrofanis, J., and Pollak, P. 2009. Deep brain stimulation of the subthalamic nucleus for the treatment of Parkinson's disease. Lancet Neurology 8(1), 6781 .

Burn, D.J., and Tröster, A.I. 2004. Neuropsychiatric complications of medical and surgical therapies for Parkinson's disease. Journal of Geriatry, Psychiatry and Neurology 17: 172-180

Christen, M., and Müller, S. 2011. Single cases promote knowledge transfer in the field of DBS. Frontiers in Integrative Neuroscience. May 2011, 5, Article 13.

Defer, G. L., Widner, H., Marié, R. M., Rémy, P., and Levivier, M. 1999. Core Assessment Program for Surgical Interventional Therapies in Parkinson's Disease (CAPSIT-PD). Movement Disorders 14: 572-584.

Hariz, M. I., Rehncrona, S., Quinn, N. P., Speelman, J. D., Wensing, C., and the Multicen-tre Advanced Parkinson's Disease Deep Brain Stimulation Group. 2008. Multicenter study on deep brain stimulation in Parkinson's disease: An independent assessment of reported adverse events at 4 years. Movement Disorders 23(3): 416-421. 
Hariz, M.I., Blomstedt, P., and Zrinzo, L. 2010. Deep brain stimulation between 1947 and 1987: the untold story. Neurosurg Focus, 29(2): E1.

Krack, P., Hariz, M.I., Baunez, C., Guridi, J., and Obeso, J.A. 2010. Deep brain stimulation: from neurology to psychiatry? Trends Neurosci. 33(10): 474-484.

Krug, H., Müller, O., and Bittner, U. 2010. Technological Interventions in the Self? An Ethical Evaluation of Deep Brain Stimulation Relating to Patient Narratives. Vortschr. Neurol. Psychiat. 78: 644-651.

Kulisevsky, J., Pagonabarraga, J., Pascual-Sedano, B., García-Sánchez, C., and Gironell, A. 2008. Prevalence and correlates of neuropsychiatric symptoms in Parkinson's disease without dementia. Movement Disorders 15;23 (13): 1889-1896.

Marani, E., Heida, T., Lakke, E.A., and Usunoff, K.G. 2008. The subthalamic nucleus. Part I: development, cytology, topography and connections. Adv Anat Embryol Cell Biol. 198: 1113.

Martinez-Martin P, and Deuschl G. 2007. Effect of medical and surgical interventions on health-related quality of life in Parkinson's disease. Movement Disorders 22(6): 757-765.

Morrison, C.E., Borod, J.C., Brin, M.F., Raskin, S.A., Germano, I.M., Weisz, D.J., and Olanow, C.W. 2000. A program for neuropsychological investigation of deep brain stimulation (PNIDBS) in movement disorder patients: Development, Deasibility, and preliminary data. Neuropsychiatry, Neuropsychology and Behavioral Neurology 13(3): 204219.

Müller, S., and Christen, M. 2011. Deep Brain Stimulation in Parkinsonian Patients - Ethical Evaluation of Cognitive, Affective, and Behavioral Sequelae', AJOB Neuroscience 2(1): 3-13.

Olanow, C.W. 2002. Surgical therapy for Parkinson's disease. European Journal of Neurology 9 (Suppl. 3): 31-39.

Pillon, B. 2002. Neuropsychological Assessment for Management of Patients with deep brain stimulation. Movement Disorders 17(supplement 3): S116-S122.

Pollak, P., Benabid, A.L., Gross, C., Gao, D.M., Laurent, A., Benazzouz, A., Hoffmann, D., Gentil, M., and Perret, J. 1993. Effets de la stimulation du noyau sous-thalamique dans la maladie de Parkinson. Revue Neurologique (Paris), 149(3): 175-176.

Saint-Cyr, J. A., and Trépanier, L. L. 2000. Neuropsychologic Assessment of Patients for Movement Disorder Surgery. Movement Disorders 15(5): 771-783.

Santarelli, L., Saxe, M., Gross, C., Surget, A., Battaglia, F., Dulawa, S., Weisstaub, N., Lee, J., Duman, R., Arancio, O., Belzung, C., and Hen, R. 2003. Requirement of Hippocampal Neurogenesis for the Behavioral Effects of Antidepressants. Science 301, 805-809.

Siegfried, J., and Blons, S. 1997. The Neurosurgical treatment of Parkinson's disease and other movement disorders. William \& Wilkins Europe Ltd, London. 
Voon, V., Kubu, C., Krack, P., Houeto, J. L., and Tröster, A. I. 2006. Deep brain stimulation: Neuropsychological and neuropsychiatric issues. Movement Disorders 21 (Suppl. 14): S305S326.

Woods, S.P., Rippeth, J.D., Conover, E., Carey, C.L., Parsons, T.D., and Tröster, A.I. 2006. Statistical Power of Studies Examining the Cognitive Effects of Subthalamic Nucleus Deep Brain Stimulation in Parkinson's Disease. The Clinical Neuropsychologist, 20(1): 27-38.

\footnotetext{
${ }^{\mathrm{i}}$ Each study was assigned with points as follows: Study was prospective: +1 ; study was case-controlled with at least 20 participants in each branch: +2 (+1 if less than 20 participants in either branch); study was randomized: +1 ; test evaluation was blinded: +1 ; study involved more than one center: +1 ; the pre-surgery and post-surgery assessment of the neuropsychiatric tests were made in the "best" (pre: med-on/ post: med-on, stim-on) condition of the patient: $+2(+1$ if the assessments were made pre and post); the study involved at least 20 patients: +1 ; the study had a follow-up time of at least 12 month: +1 ; the study involved tests of at least three issue classes: +1 . ii The citation coefficient was construed as follows: We counted the appearance of outcome studies in the analytic part of reviews that either performed a meta-analysis following established standards (e.g. Cochrane) or were at least systematically evaluated (i.e. we excluded merely narrative reviews; thus we considered 23 reviews). The citation of outcome papers is weighted with the probability of being able to be cited due to the year of publication to take into account, that a paper e.g. published in 2006 cannot be cited in a review published in 2004. Thus each outcome paper received a citation coefficient value between 0 and 1 . For the correlation analysis, only outcomes with nonzero citation coefficient have been analyzed.
} 


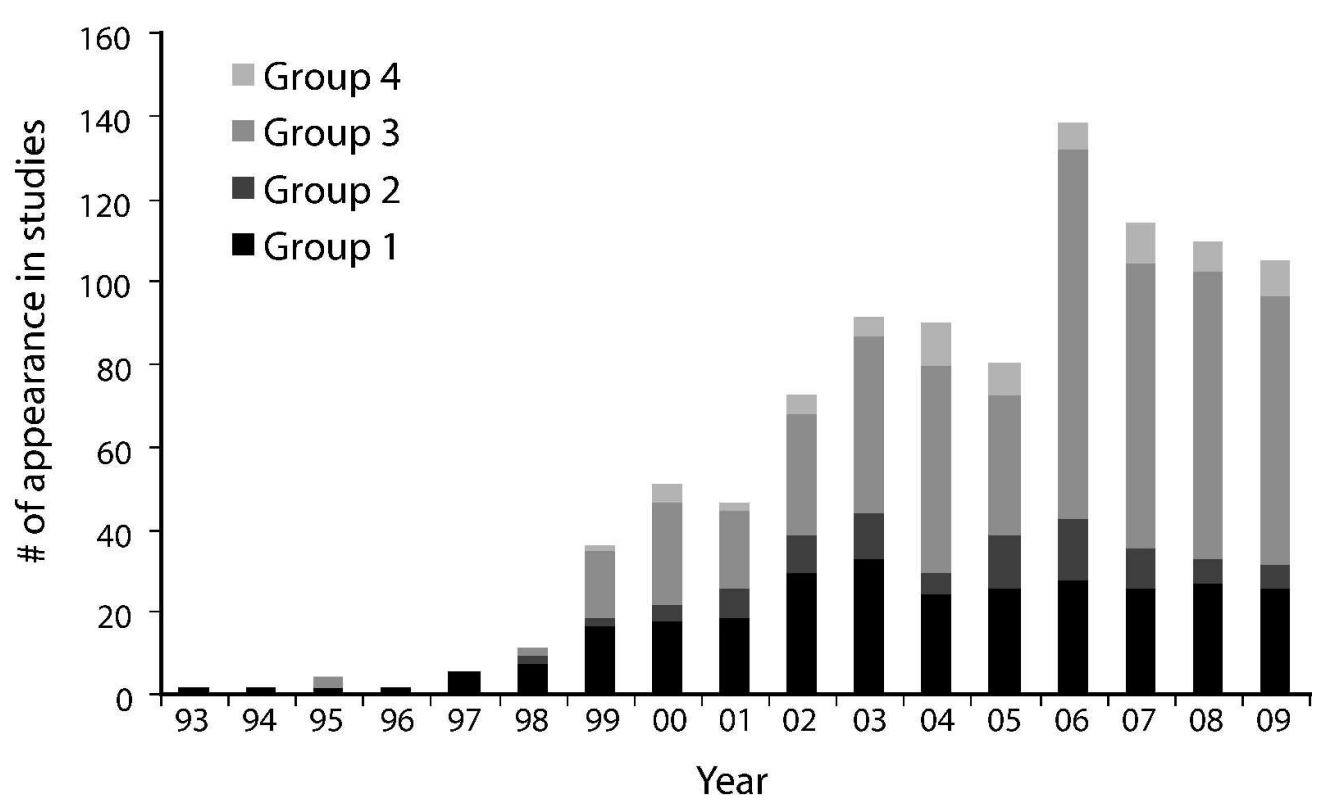

The histogram displays the total number of issues (compare with Table 2) addressed in the publications about STN-DBS (case reports, reviews, and outcome studies) pooled in four groups (Group 1: F, M, V / Group 2: O, P, T / Group 3: B, C, D, L, Q / Group 4: A, E, I, K, N, S, W; see text).

$134 \times 80 \mathrm{~mm}(600 \times 600 \mathrm{DPI})$ 
a)

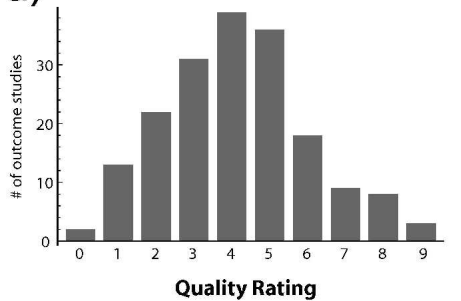

b)

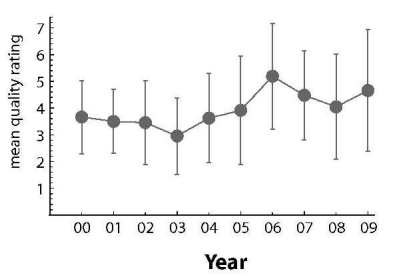

c)

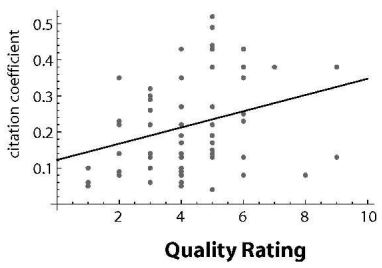

(a) Quality rating distribution of the outcome studies of group 3, (b) time-course of the mean quality rating of outcome studies (group 3), (c) correlation between the citation coefficient of studies (which reflects the appreciation of papers by the authors of reviews) with the quality rating of the studies. The chart also includes the linear approximation of the correlation. $165 \times 43 \mathrm{~mm}(600 \times 600 \mathrm{DPI})$ 
a)

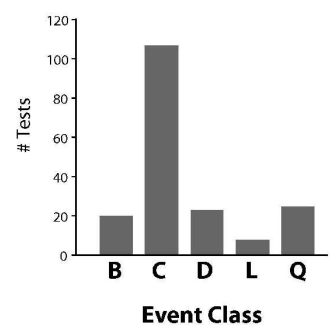

b)

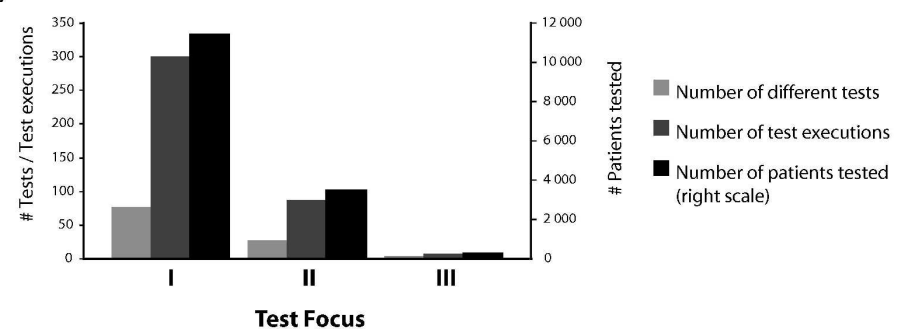

a: Number of tests per issue class (B: behavioral, C: cognitive, D: depression and other mood issues, L: language, Q: quality of life). b: Number of different tests (first bar in each group), of accumulated test executions (middle bar) and total number of patients tested (left bar, right scale) with methods of either class I (test scores generated by evaluator), II (self-assessment of patient) or III (test scores emerge from persons affiliated to the patient). $189 \times 54 \mathrm{~mm}(600 \times 600 \mathrm{DPI})$ 


\begin{tabular}{|l|l|l|l|}
\cline { 3 - 4 } \multicolumn{2}{c|}{} & \multicolumn{2}{c|}{ Predictability of side effects (SE) of a therapy } \\
\cline { 3 - 4 } \multicolumn{2}{c|}{$\begin{array}{l}\text { predictable } \\
\text { The SE of the therapy } \\
\text { clearly outweighs its } \\
\text { therapeutic effects. }\end{array}$} & Do not begin / stop the therapy. & Ensure sensibility for novel SE. \\
\cline { 2 - 4 } & $\begin{array}{l}\text { There are conflicting } \\
\text { evaluations of the SE } \\
\text { by different } \\
\text { stakeholders. }\end{array}$ & $\begin{array}{l}\text { Define the authority to decide about } \\
\text { the usage of the therapy. }\end{array}$ & $\begin{array}{l}\text { Ensure involvement of different } \\
\text { stakeholder's perspectives during the } \\
\text { development of the therapy. }\end{array}$ \\
\cline { 2 - 4 } & $\begin{array}{l}\text { The therapeutic } \\
\text { effects clearly } \\
\text { outbalance the SE. }\end{array}$ & $\begin{array}{l}\text { Define a procedure to take individual } \\
\text { variability of the impact of the SE } \\
\text { into account. }\end{array}$ & $\begin{array}{l}\text { Define a procedure to decide whether } \\
\text { a novel SE is classified as } \\
\text { unproblematic or not. }\end{array}$ \\
\hline
\end{tabular}




\begin{tabular}{|c|c|c|c|}
\hline & Abbr. & Issue class & Examples of side effects \\
\hline \multirow{3}{*}{ 言 } & $\mathrm{F}$ & $\begin{array}{l}\text { Functional studies, i.e. studies that involve PET } \\
\text { or other methods for investigating the causal } \\
\text { effect of DBS }\end{array}$ & - \\
\hline & $\mathrm{M}$ & Motor effects & $\begin{array}{l}\text { Apraxia, axial symptoms, dyskinesia, dystonia, } \\
\text { gait disorders, motor fluctuations }\end{array}$ \\
\hline & $\mathrm{V}$ & $\begin{array}{l}\text { Issues related to Levodopa and other } \\
\text { medication }\end{array}$ & $\begin{array}{l}\text { Dopamine dysregulation syndrome, changes in } \\
\text { LEDD }\end{array}$ \\
\hline \multirow{3}{*}{ 言 } & $\mathrm{O}$ & Operation/surgery related issues & $\begin{array}{l}\text { Hemorrhage, hematoma, ischemia, surgical } \\
\text { complications, infections }\end{array}$ \\
\hline & $\mathrm{P}$ & $\begin{array}{l}\text { Patient issues, i.e. issues related to patient } \\
\text { selection, patient management, rehabilitation }\end{array}$ & - \\
\hline & $\mathrm{T}$ & Effects related to the technology (device) & $\begin{array}{l}\text { Battery problems, electrode break, local infections, } \\
\text { lead fracture, pulse generator malfunction }\end{array}$ \\
\hline \multirow{5}{*}{ 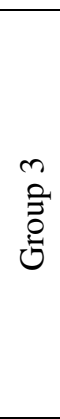 } & B & $\begin{array}{l}\text { Behavioral effects, i.e. effects that concern } \\
\text { abnormal behavior }\end{array}$ & $\begin{array}{l}\text { Compulsive shopping, hypersexuality, hypomania, } \\
\text { pathological gambling, suicide (attempts) }\end{array}$ \\
\hline & $\mathrm{C}$ & Effects on cognition (reasoning, memory etc.) & $\begin{array}{l}\text { Cognitive decline, confusion, dementia, memory } \\
\text { decline, verbal fluency }\end{array}$ \\
\hline & $\mathrm{D}$ & $\begin{array}{l}\text { Depression, anxiety, apathy and other mood } \\
\text { effects }\end{array}$ & $\begin{array}{l}\text { Ahedonia, apathy, depression, mood changes, } \\
\text { sadness }\end{array}$ \\
\hline & $\mathrm{L}$ & $\begin{array}{l}\text { Language, i.e. effects regarding the general } \\
\text { speech ability and motor aspects of speech }\end{array}$ & $\begin{array}{l}\text { Aphasia, dysarthria, hypophonia, speech } \\
\text { impairment, voice freezing }\end{array}$ \\
\hline & $\mathrm{Q}$ & Quality of life and social aspects & $\begin{array}{l}\text { Disability in daily living, decreased life } \\
\text { satisfaction, partnership problems }\end{array}$ \\
\hline \multirow{7}{*}{ 苛 } & A & $\begin{array}{l}\text { Effects regarding the autonomous nervous } \\
\text { system, autonomous functioning }\end{array}$ & Drooling, dysphagia, hyperhidrosis \\
\hline & $\mathrm{E}$ & Emotion recognition changes & $\begin{array}{l}\text { Difficulties of emotion discrimination, difficulties } \\
\text { of face perception, hyperemotivity }\end{array}$ \\
\hline & I & Insomnia, i.e. effects related to sleep & Drowsiness, fatigue, insomnia, sleep disorders \\
\hline & $\mathrm{K}$ & $\begin{array}{l}\text { Cost issues (German: Kosten), i.e. cost-benefit- } \\
\text { studies, cost-effectiveness of DBS etc. }\end{array}$ & -2 \\
\hline & $\mathrm{N}$ & Other neurological effects & Epilepsy, postural imbalance, seizures \\
\hline & $\mathrm{S}$ & Effects regarding sensory systems & Blurred vision, parasthesia, visual hallucinations \\
\hline & $\mathrm{W}$ & Weight and energy intake changes & Abnormal weight gain, binge eating, obesity \\
\hline
\end{tabular}




\title{
Christen M, Müller S, Bittlinger M, Walter H, and Brugger P: Dealing with Side Effects of Deep Brain Stimulation: Lessons Learned from Stimulating the STN
}

\author{
Supplementary Material
}

\section{List of Case Reports (66)}

Alesch F. 2005. Sudden failure of dual channel pulse generators. Movement Disorders 20: 64-66.

Balash Y, Merims D, Giladi N. 2007. Suicidal thoughts in patients with Parkinson's disease treated by deep brain stimulation of the subthalamic nuclei: Two case reports and review of the literature. Acta Neuropsychiatrica 19(3): 208-210

Bandini Fabio, Primavera Alberto, Pizzorno Matteo, Cocito Leonardo. 2007. Using STN DBS and medication reduction as a strategy to treat pathological gambling in Parkinson's disease. Parkinsonism and Related Disorders 13: 369-371

Bejjani BP, Damier P, Arnulf I, Thivard L, Bonnet AM, Dormont D, Cornu P, Pidoux B, Samson Y, Agid Y. 1999. Transient acute depression induced by high-frequency deep-brain stimulation. The New England Journal of Medicine 340(19): 1476-1480

Bejjani BP, Houeto JL, Hariz M, Yelnik J, Mesnage V, Bonnet AM, Pidoux B, Dormont D, Cornu P, Agid Y. 2002. Aggressive behavior induced by intraoperative stimulation in the triangle of Sano. Neurology 59: $1425-1427$

Benabid AL, Pollak P, Gross C, Hoffmann D, Benazzouz A, Gao DM, Laurent A, Gentil M, Perret J. 1994. Acute and long-term effects of subthalamic nucleus stimulation in Parkinson's disease. Stereotactic and Functional Neurosurgery 62: 76-84

Blomstedt P, Hariz MI, Lees A, Silberstein P, Limousin P, Yelnik J, Agid Y. 2008. Acute severe depression induced by intraoperative stimulation of the substantia nigra: A case report. Parkinsonism and Related Disorders 14: 253-256

Burghaus L, Hilker R, Thiel A, Galldiks N, Lehnhardt FG, Zaro-Weber O, Sturm V, Heiss W-D. 2006. Deep brain stimulation of the subthalamic nucleus reversibly deteriorates stuttering in advanced Parkinson's disease. Journal of Neural Transmission 113: 625-631

Cabo JAV, Barragan L. 2007. Perioperative care in subthalamic stimulation surgery. Neurologia 22(1): 49-53

Cakmakli GY, Oruckaptan H, Saka E, Elibol B. 2009. Reversible acute cognitive dysfunction induced by bilateral STN stimulation. Journal of Neurology 256(8): 1360-1362

Capecci M, Passamonti L, Annesi F, Annesi G, Bellesi M, Candiano ICC, Ricciuti R, Iacoangeli M, Scerrati M, Zappia M, Tarantino P, De Marco EV, Civitelli D, Carrideo S, Provinciali L, Ceravolo MG, Quattrone A. 2004. Chronic Bilateral Subthalamic Deep Brain Stimulation in a Patient With Homozygous Deletion in the Parkin Gene. Movement Disorders 19(12): 2004

Cersosinio MG, Piedimonte F, Raina GB, Micheli FE. 2007. Bilateral STN-DBS fails to improve non-motor fluctuations in a PD patient. Parkinsonism and Related Disorders 13(8): 537-538

Chen Shin-Yuan, Lin Shinn-Zong, Lee Tien-Wen. 2004. Subthalamic nucleus stimulation and the development of delusion. Journal of Psychiatric Research 38: 637-638

Christine CW, Langston JW, Turner RS, Starr PA. 2009. The neurophysiology and effect of deep brain stimulation in a patient with 1-methyl-4-phenyl-1,2,3,6-tetrahydropyridine-induced Parkinsonism: Case report. Journal of Neurosurgery 110(2): 234-238

Czerneck V, Schupbach M, Yaici S, Levy R, Bardinet E, Yelnik J, Dubois B, Agid Y. 2008. Apathy Following Subthalamic Stimulation in Parkinson Disease: A Dopamine Responsive Symptom. Movement Disorders 23(7): 964-969

Diederich NJ, Alesch F, Goetz CG. 2000. Visual Hallucinations Induced by Deep Brain Stimulation in Parkinson's Disease. Clinical Neuropharmacology 23(5): 287-289

Doshi P, Bhargava P. 2008. Hypersexuality following subthalamic nucleus stimulation for Parkinson's disease. Neurology India 56: 474-476

Doshi PK, Chhaya N, Bhatt MH. 2002. Depression Leading to Attempted Suicide After Bilateral Subthalamic Nucleus Stimulation for Parkinson's Disease. Movement Disorders 17(5): 1084-1100

Farris S, Ford P, DeMarco J, Giroux ML. 2008. Deep Brain Stimulation and the Ethics of Protection and Caring for the Patient with Parkinson's Dementia. Movement Disorders 23(14): 1973-1976

Figueiras-Méndez R, Marín-Zarza F, Antonio Molina J, Jiménez-Jiménez FJ, Ortí-Pareja M, Magariños C, López-Pino MA, Martínez V. 1999. Subthalamic nucleus stimulation improves directly levodopa induced dyskinesias in Parkinson's disease. Journal of Neurology, Neurosurgery and Psychiatry 66(4): 549-50.

Gentil M, Tournier CL, Pollak P, Benabid AL. 1999. Effect of bilateral subthalamic nucleus stimulation and dopatherapy on oral control in Parkinson's disease. European Neurology 42: 136-140 
Goto S, Yamada K, Ushio Y. . 2004. Subthalamic nucleus stimulation in a parkinsonian patient with previous bilateral thalatomy. Journal of Neurology Neurosurgery and Psychiatry 75: 163-171

Goyal V, Vaishya S, Shukla G, Singh S, Behari M. 2009. Unusual Complication of Deep Brain Stimulation in Parkinson's Disease. Movement Disorders 24(8): 1251-1252.

Hamel W, Schrader B, Weinert D, Herzog J, Müller D, Deuschl G, Volkmann J, Mehdorn HM. 2002. Technical complication in deep brain stimulation. Zentralbibliothek für Neurochirurgie 63: 124-27.

Hariz MI, Johansson F, Shamsgovara P, Johansson E, Hariz G-M, Fagerlund M. 2000. Bilateral Subthalamic Nucleus Stimulation in a Parkinsonian Patient With Preoperative Deficits in Speech and Cognition: Persistent Improvement in Mobility But Increased Dependency: A Case Study. Movement Disorders 15(1): 136-139

Hariz MI, Johansson F. 2001. Hardware failure in parkinsonian patients with chronic subthalamic nucleus stimulation is a medical emergency. Movement Disorders 16(1): 166-168

Herzog J, Reiff J, Krack P, Witt K, Schrader B, Müller D, Deuschl G. 2003. Manic episode with psychotic symptoms induced by subthalamic nucleus stimulation in a patient with Parkinson's disease. Movement Disorders 18(11): 1382-1384

Hettige S, Samuel M, Clough C, Hulse N, Ashkan K. 2009. Deep Brain Stimulation for Parkinson's Disease when HIV Coexists. Movement Disorders 24(14): 2169-2170

Hilker R, Voges J, Thiel A, Ghaemi M, Herholz K, Sturm V, Heiss W-D. 2002. Deep brain stimulation of the subthalamic nucleus versus levodopa challenge in Parkinson's disease: measuring the on- and offconditions with FDG-PET. Journal of Neural Transmissions 109: 1257-1264

Houeto JL, Bejjani PB, Damier P, Staedler C, Bonnet AM, Pidoux B, Dormont D, Cornu P, Agid Y. 2000. Failure of long-term pallidal stimulation corrected by subthalamic stimulation in PD. Neurology 55: 728730

Jarraya B, Bonnet A-M, Duyckaerts C, Houeto J-L, Cornu P, Hauw J-J, Agid Y. 2003. Parkinson's Disease, Subthalamic Stimulation, and Selection of Candidates: A Pathologic Study. Movement Disorders 18(2): $1517-1520$

Knobel D, Aybek S, Pollo C, Vingerhoets FJG, Berney A. 2008. Rapid resolution of Dopamine Dysregulation Syndrome (DDS) after Subthalamic DBS for Parkinson Disease (PD). Cognitive and Behavioral Neurology 21(3): 187-189

Krack P, Kumar R, Ardouin C, Limousin Dowsey P, McVicker JM, Benabid AL, Pollak P. 2001. Mirthful Laughter Induced by Subthalamic Nucleus Stimulation. Movement Disorders 16(5): 867-875

Kulisevsky J, Berthier ML, Gironell A, Pascual-Sedano B, Molet J, Parés P. 2002. Mania following deep brain stimulation for Parkinson's disease. Neurology 59: 1421-1424

Leentjens AFG, Visser-Vandewalle V, Temel Z, Verhey FRJ. 2004. Manipuleerbare wilsbekwaamheid: een ethisch probleem bij elektrostimulatie van de nucleus subthalamicus voor ernstige ziekte van Parkinson. Ned Tijdschr Geneeskd 10 148(28): 1394-1398

Lilleeng B, Dietrichs E. 2008. Unmasking psychiatric symptoms after STN deep brain stimulation in Parkinson's disease. Acta Neurologica Scandinavia 117 (suppl. 188): 41-45

Limousin P, Pollak P, Benazzouz A, Hoffmann D, Broussolle E, Perret JE, Benabid A-L. 1995. Bilateral Subthalamic Nucleus Stimulation for Severe Parkinson's Disease. Movement Disorders 10(5): 672-674

Limousin P, Pollak P, Hoffmann D, Benazzouz A, Perret JE, Benabid A-L. 1996. Abnormal Involuntary Movements Induced by Subthalamic Nucleus Stimulation in Parkinsonian Patients. Movement Disorders 11(3): 231-235

Low Hu L, Sayer FT, Honey CR. 2008. Pathological Crying Caused by High-Frequency Stimulation in the Region of the Caudal Internal Capsule. Archives of Neurology 65(2): 264-266

Machado AG, Hiremath GK, Salazar F, Rezai AR. 2005. Fracture of subthalamic nucleus deep brain stimulation hardware as a result of compulsive manipulation: Case report. Neurosurgery 57(6): E1318-1-E1318-5

Mallet L, Schüpbach M, N'Diaye K, Remy P, Bardinet E, Czernecki V, Welter ML, Pelissolo A, Ruberg M, Agid Y, Yelnik J. 2007. Stimulation of subterritories of the subthalamic nucleus reveals its role in the integration of the emotional and motor aspects of behavior. PNAS 104(25): 10661-10666

Mallet L, Mesnage V, Houeto J-L, Pelissolo A, Yelnik J, Behar C, Gargiulo M, Welter M-L, Bonnet A-M, Pillon B, Cornu P, Dormont D, Pidoux B, Allilaire J-F, Agid Y. 2002. Compulsions, Parkinson's disease, and stimulation. Lancet 360: 1302-1304

Mandat TS, Hurwitz T, Honey CR. 2006. Hypomania as an adverse effect of subthalamic nucleus stimulation: report of two cases. Acta Neurochirurgica (Wien) 48: 895-898

Merello M, Cammarota A, Leiguarda R, Pikielny R. 2001. Delayed intracerebral electrode infection after bilateral STN implantation for Parkinson's disease. Case report. Movement Disorders 16(1): 168-170.

Moreau C, Defebvre L, Devos D, Marchetti F, Destée A, Stefani A, Peppe A. 2009. STN versus PPN-DBS for alleviating freezing of gait: toward a frequency modulation approach? Movement Disorders 24(14): 21642166. 
Moretti R, Torre P, Antonello RM, Calus L, Gioulis M, Marsala SZ, Cazzato G, Bava A. 2002. Cognitive changes following subthalamic nucleus stimulation in two patients with Parkinson's disease. Perception and Motor Skills 95: 477-486

Moretti R, Torre P, Antonello RM, Capus L, Gioulis M, Marsala SZ, Cazzato G, Bava A. 2001. Effects on cognitive abilities following subthalamic nucleus stimulation in Parkinson's disease. European Journal of Neurology 8(6): 726-727

Morgan JC, diDonato CJ, Jenkins PD, Sethi KD. 2006. Self-stimulatory behavior associated with deep brain stimulation in Parkinson's disease. Movement Disorders 21(2): 283-285

Novak KE, Nenonene EK, Bernstein LP, Vergenz S, Medalle G, Prager JM, Eller TW, Cozzens JW, Rezak M. 2006. Two cases of ischemia associated with subthalamic nucleus stimulator implantation for advanced Parkinson's disease. Movement Disorders 21: 1477-83.

Okun MS, Raju DV, Walter BL, Juncos JL, DeLong MR, Heilman K, McDonald WM, Vitek JL. 2004. Pseudobulbar crying induced by stimulation in the region of the subthalamic nucleus. Journal of Neurology Neurosurgery and Psychiatry 75: 921-923

Piasecki SD, Jefferson JW. 2004. Psychiatric Complications of Deep Brain Stimulation for Parkinson's Disease. Journal of Clinical Psychiatry 65: 845-849

Pinto S, Gentil M, Krack P, Sauleau P, Fraix V, Benabid AL, Pollak P. 2005. Changes induced by levodopa and subthalamic nucleus stimulation on parkinsonian speech. Movement Disorders 20: 1507-1515.

Pollak P, Benabid AL, Gross C, Gao DM, Laurent A, Benazzouz A, Hoffmann D, Gentil M, Perret J. 1993. Effets de la stimulation du noyau sous-thalamique dans la maladie de parkinson. Revue Neurologique (Paris) 149(3): 175-176

Raucher-Chéné D, Charrel C-L, Doe de Maindreville A, Limosin F. 2008. Manic episode with psychotic symptoms in a patient with Parkinson's disease treated by subthalamic nucleus stimulation: Improvement on switching the target. Journal of the Neurological Sciences 273: 116-117

Roark C, Whicher S, Abosch A. 2008. Reversible neurological symptoms caused by diathermy in a patient with deep brain stimulators: Case Report. Neurosurgery 62: E256

Romito LM, Raja M, Daniele A, Contarino MF, Bentivoglio AR, Barbier A, Scerrati M, Albanese A. 2002. Transient Mania with Hypersexuality After Surgery for High-Frequency Stimulation of the Subthalamic Nucleus in Parkinson's Disease. Movement Disorders 17(6): 1371-1374

Sensi M, Eleopra R, Cavallo MA, Sette E, Milani P, Quatrale R, Capone JG, Tugnoli V, Tola MR, Granieri E, Data PG. 2004. Explosive-aggressive behavior related to bilateral subthalamic stimulation. Parkinsonism and Related Disorders 10 (2004) 247-251

Smeding, HM, Goudriaan AE, Foncke EMJ, Schuurman PR, Speelman JD, Schmand B. 2007. Pathological gambling after bilateral subthalamic nucleus stimulation in Parkinson disease. Journal of Neurology, Neurosurgery \& Psychiatry 78(5): 517-519

Stefurak T, Mikulis D, Mayberg H, Lang AE, Hevenor S, Pahapill P, Saint-Cry J, Lozano A. 2003. Deep brain stimulation for Parkinson's disease dissociates mood and motor circuits: A functional MRI case study. Movement Disorders 18(12): 1508-1516

Tarsy D, Apetauerova D, Ryan P, Norregaard T. 2003. Adverse effects of subthalamic nucleus DBS in a patient with multiple system atrophy. Neurology 61(2): 247-249

Tommasi G, Lanotte M, Albert U, Zibetti M, Castelli L, Maina H, Lopiano L. 2008. Transient acute depressive state induced by subthalamic region stimulation. Journal of the Neurological Sciences 273: 135-138

Tsai ST, Lin SH, Lin S-Z, Chen J-Y, Lee C-W, Chen S-Y. 2007. Neuropsychological effects after chronic subthalamic stimulation and the topography of the nucleus in Parkinson's disease. Neurosurgery 61(5): 1024-1029

Ulla M, Thobois S, Lemaire J-J, Schmitt A, Derost P, Broussolle E, Llorca P-M, Durif F. 2006. Manic behaviour induced by deep-brain stimulation in Parkinson's disease: evidence of substantia nigra implication? Journal of Neurology Neurosurgery and Psychiatry 77: 1363-1366

Valldeoriola F, Tolosa E, Alegret M. 2006. Cognitive changes in Parkinson's disease during subthalamic stimulation: a clinicopathologic study. Journal of Neurology, Neurosurgery \& Psychiatry 77(4): 565-6

Walker HC, Phillips DE, Boswell DB, Guthrie BL, Guthrie SL, Nicholas AP, Montgomery EB, Watts RL. 2009. Relief of acquired stuttering associated with Parkinson's disease by unilateral left subthalamic brain stimulation. Journal of Speech, Language and Hearing Research. 52(6): 1652-1657.

Witjas T, Baunez C, Henry MJ, Delfini M, Regis J, Cherif AA, Peragut CJ, Azulay JP. 2005. Addiction in Parkinson's disease: Impact of subthalamic nucleus deep brain stimulation. Movement Disorders 20(8): $1052-1055$ 


\section{List of Review Papers (69)}

Alberts JL, Hass CJ, Vitek JL, Okun MS. 2008. Are two leads always better than one: An emerging case for unilateral subthalamic deep brain stimulation in Parkinson's disease. Experimental Neurology 214: 1-5

Amick MM, Grace J. 2006. Deep Brain Stimulation Surgery for Parkinson's Disease: The Role of Neuropsychological Assessment. Medicine and Health / Rhode Island 89(4): 130-133

Anderson KE, Mullins J. 2003. Behavioral changes associated with deep brain stimulation surgery for Parkinson's disease. Current Neurology and Neuroscience Reports 3(4): 306-313

Appleby BS, Duggan PS, Regenberg A, Rabins PV. 2007. Psychiatric and neuropsychiatric adverse events associated with deep brain stimulation: A meta-analysis of ten years' experience. Movement Disorders 22(12): 1722-1728

Ashkan K, Wallace B, Bell BA, Benabid AL. 2004. Deep brain stimulation of the subthalamic nucleus in Parkinson's Disease 1993 - 2003: where are we 10 years on? British Journal of Neurosurgery 18(1): 1934

Benabid AL. 2003. Deep brain stimulation for Parkinson's disease. Current Opinion in Neurobiology 13: 696706

Benabid AL, Benazzouz A, Hoffmann D, Limousin P, Krack P, Pollak P. 1998. Long-term electrical inhibition of deep brain targets in movement disorders. Movement Disorders 13 Suppl 3: 119-125.

Benabid AL, Chabardes S, Mitrofanis J, Pollak P. 2009. Deep brain stimulation of the subthalamic nucleus for the treatment of Parkinson's disease. Lancet Neurology 8(1): 67-81

Benabid AL, Chabardès S, Seigneuret E. 2005. Deep-brain stimulation in Parkinson's disease: long-term efficacy and safety - What happened this year? Current Opinion in Neurology 18(6): 623-30

Berney A, Vingerhoets F. 2004. Stimulation cérébrale profonde dans la maladie de Parkinson: effets moteurs et comportementaux. Schweizer Archiv für Neurologie und Psychiatrie 155(8): 399-406

Boisson D. 2008. Stimulation cérébrale profonde et maladie de Parkinson. Annales de réadaptation et de médecine physique 51 (2008) 491-500

Boucai L, Cerquetti D, Merello M. 2004. Functional surgery for Parkinson's disease treatment: a structured analysis of a decade of published literature. British Journal of Neurosurgery 18(3): 213-223

Burkhard PR, Villemure J-G, Vingerhoets FJG. 2005. Current treatment of Parkinson's disease: Problems and controversies. Revue Medicale Suisse 1(18): 1214-1219

Burn DJ, Tröster AI. 2004. Neuropsychiatric complications of medical and surgical therapies for Parkinson's disease. Journal of Geriatry, Psychiatry and Neurology 17: 172-180

Defebvre 1, Krystkowiak P, Blond S, Destée A. 2000. Stimulation électrique chronique du pallidum interne et du noyau subthalamique dans la maladie de Parkinson. Presse Medicale 29: 1525-1531

Defer GL, Widner H, Marié RM, Rémy P, Levivier M. 1999. Core assessment program for surgical interventional therapies in Parkinson's disease (CAPSIT-PD). Movement Disorders 14(4): 572-84

Deuschl G, Herzog J, Kleiner-Fisman G, Kubu C, Lozano AM, Lyons KE, Rodriguez-Oroz MC, Tamma F, Troster AI, Vitek JL, Volkmann J, Voon V. 2006. Deep Brain Stimulation: Postoperative Issues. Movement Disorders 21 (Suppl. 14): S219-S237

Deuschl G, Wenzelburger R, Kopper F, Volkmann J . 2003. Deep brain stimulation of the subthalamic nucleus for Parkinson's disease: a therapy approaching evidence-based standards. Journal of Neurology 250(1): $\mathrm{I} / 43-\mathrm{I} / 46$

Diamond A, Jankovic J. 2005. The effect of deep brain stimulation on quality of life in movement disorders. Journal of Neurology, Neurosurgery \& Psychiatry 76(9): 1188-1193

Dowsey-Limousin P, Pollak P. 2001. Deep brain stimulation in the treatment of Parkinson's disease: a review and update. Clinical Neuroscience Research 1(6): 521-526

Drapier S, Damier P. 2003. Continuous subthalamic neurostimulation in Parkinson's disease - Indications and modalities. Presse Medicale 32(28): 1334-1339

Fields Julie A, Tröster Alexander I. 2000. Cognitive Outcomes after Deep Brain Stimulation for Parkinson's Disease: A Review of Initial Studies and Recommendations for Future Research. Brain and Cognition 42, 268-293 (2000)

Fogel W, Krause M, Tronnier VM. 2000. Ergebnisse der STN-Stimulation im Vergleich mit anderen stereotaktischen Verfahren. Akt Neurol 27 Supplement 1: S9-S15

Goetz CG, Poewe W, Rascol O, Sampaio C. . 2005. Evidence-based medical review update: pharmacological and surgical treatments of Parkinson's disease: 2001 to 2004. Movement Disorders 20(5): 523-39.

Goodman RR, Kim B, McClelland III S, Senatus PB, Winfield LM, Pullman SL, Yu Q, Ford B, McKhann II GM. 2006. Operative techniques and morbidity with subthalamic nucleus deep brain stimulation in 100 consecutive patients with advanced Parkinson's disease. Journal of Neurology Neurosurgery and Psychiatry 77: 12-17 
Hallett M, Litvan I. 1999. Evaluation of surgery for Parkinson's disease: a report of the Therapeutics and Technology Assessment Subcommittee of the American Academy of Neurology. The Task Force on Surgery for Parkinson's Disease. Neurology 53(9): 1910-1921

Halpern CH, Rick JH, Danish SF, Grossman M, Baltuch GH . 2009. Cognition following bilateral deep brain stimulation surgery of the subthalamic nucleus for Parkinson's disease. International Journal of Geriatric Psychiatry 24: 443-451

Hamani C, Lozano AM. 2006. Hardware-related complications of deep brain stimulation: a review of the published literature. Stereotactic and Functional Neurosurgery 84: 248-51

Hamani C, Richter E, Schwalb JM, Lozano AM. 2005. Bilateral subthalamic nucleus stimulation for Parkinson's disease: A systematic review of the clinical literature. Neurosurgery 56(6): 1313-1321

Hariz MI. 2000. Pros and Cons of Various stereotactic procedures for Parkinson's Disease. Pan Arab Neurosurgery 4(2)

Hariz MI. 2002. Complications of deep brain stimulation. Movement disorders 17(S3): S162-166

Herzog J, Deuschl G, Volkmann J. 2003. Deep brain stimulation in the treatment of idiopathic Parkinson's disease. Nervenheilkunde: Zeitschrift für interdisziplinaere Fortbildung 22(10): 498-503

Herzog J, Deuschl G, Volkmann J. 2008. Tiefe Hirnstimulation bei der Parkinsonschen Krankheit. Nervenheilkunde 27: 403-412

Israel Z, Hassin-Baer S. 2005. Subthalamic Stimulation for Parkinson's Disease. IMAJ 7: 458-463

Karner E, Wolf E, Poewe W, Benke T. 2004. Neuropsychologische Befunde bei Stimulation der Basalganglien ein Review. Zeitschrift für Neuropsychologie, 15 (4), 2004, 287-301

Kirsch-Darrow L, Mikos A, Bowers D. 2008. Does deep brain stimulation induce apathy in parkinson's disease? Frontiers in Bioscience May 1: 5316-5322

Kleiner-Fisman G, Herzog J, Fisman DN, Tamma F, Lyons KE, Pahwa R, Lang AE, Deuschl G. 2006. Subthalamic Nucleus Deep Brain Stimulation: Summary and Meta-Analysis of Outcomes. Movement Disorders 21(14): S290-S304

Koller WC, Pahwa R, Lyons KE, Albanese A. 1999. Surgical treatment of Parkinson's disease. Journal of the Neurological Sciences 167(1): 1-10

Krack P, Fraix V, Mendes A, Benabid A-L, Pollak P. 2002. Postoperative Management of Subthalamic Nucleus Stimulation for Parkinson's Disease. Movement Disorders 17 (Suppl. 3): S188-S197

Krack P, Hamel W, Mehdorn HM, Deuschl G . 1999. Surgical treatment of Parkinson's disease. Current Opinion in Neurology 12(4): 417-25

Lefaucheur J-P, Gurruchaga J-M, Pollin B, von Raison F, Mohsen N, Shin M, Ménard-Lefaucheur I, Oshino S, Kishima H, Fénelon G, Rémy P, Cesaro P, Gabriel I, Brugières P, Keravel Y, Nguyen J-P. 2008. Outcome of Bilateral Subthalamic Nucleus Stimulation in the Treatment of Parkinson's Disease: Correlation with Intra-Operative Multi-Unit Recordings but Not with the Type of Anaesthesia. European Neurology 60: 186-199

Limousin P, Martinez-Torres I. 2008. Deep brain Stimulation for Parkinson's Disease. Neurotherapeutics 5: 309-319

Limousin-Dowsey P, Pollak P, Van Blercom N, Krack P, Benazzouz A, Benabid AL. 1999. Thalamic, subthalamic nucleus and internal pallidum stimulation in Parkinson's disease. Journal of Neurology 246 (Suppl. 2): II/42-II/45

Martinez-Martin P, Deuschl G. 2007. Effect of medical and surgical interventions on health-related quality of life in Parkinson's disease. Movement Disorders 22(6): 757-65.

Meagher LJ, Ilchef R, Silberstein P, Cook RJ, Wasson D, Malhi GS. 2008. Psychiatric morbidity in patients with Parkinson's disease following bilateral subthalamic deep brain stimulation: literature review. Acta Neuropsychiatrica 20: 182-192

Morrison CE, Borod JC, Brin MF, Raskin SA, Germano IM, Weisz DJ, Olanow CW. 2000. A program for neuropsychological investigation of deep brain stimulation (PNIDBS) in movement disorder patients: Development, Feasibility, and preliminary data. Neuropsychiatry, Neuropsychology and Behavioral Neurology 13(3): 204-219

Okun MS, Rodriguez RL, Mikos A, Miller K, Kellison I, Kirsch-Darrow L, Wint DP, Springer U, Fernandez HH, Foote KD, Crucian G, Bowers D. 2007. Deep brain stimulation and the role of the neuropsychologist. Clinical Neuropsychology 21(1):162-189

Olanow CW, Brin MF, Obeso JA. 2000. The role of deep brain stimulation as a surgical treatment for Parkinson's disease. Neurology 55(12) Supplement 6: S60-S66

Panikar D, Kishore A. 2003. Deep brain stimulation for Parkinson's disease. Neurology India 51(2): 167-75

Parsons TD, Rogers SA, Braaten AJ, Woods SP, Tröster AI. 2006. Cognitive sequelae of subthalamic nucleus deep brain stimulation in Parkinson's disease: a meta-analysis. Lancet Neurology 5: 578-588

Piasecki SD, Jefferson JW. 2004. Psychiatric Complications of Deep Brain Stimulation for Parkinson's Disease. Journal of Clinical Psychiatry 65: 845-849

Pillon B. 2002. Neuropsychological Assessment for Management of Patients with deep brain stimulation. Movement Disorders 17(supplement 3): S116-S122 


\section{List of Outcome Studies (347)}

Aybek S, Lazeyras F, Gronchi-Perrin A, Burkhard PR, Villemure JG, Vingerhoets FJ. 2009. Hippocampal atrophy predicts conversion to dementia after STN-DBS in Parkinson's disease. Parkinsonism and Related Disorders 15(7): 521-4

Accolla E, Caputo E, Cogiamanian F, Tamma F, Mrakic-Sposta S, Marceglia S, Egidi M, Rampini P, Locatelli M, Priori A. 2007. Gender differences in patients with Parkinson's disease treated with subthalamic deep brain stimulation. Movement Disorders 22(8): 1150-1156

Agostino R, Dinapoli L, Modugno N, Iezzi E, Gregori B, Esposito V, Romanelli P, Berardelli A. 2008. Ipsilateral sequential arm movement after unilateral subthalamic deep brain stimulation in Patients with Parkinson's disease. Movement Disorders 23(12): 1718-1724

Albanese A, Piacentini S, Romito LMA, Leone M, Franzini A, Broggi G, Bussone G, Burkhard PR, Ghika J, Berney A, Villemure J-G, Vingerhoets FJG. 2005. Suicide after successful deep brain stimulation for movement disorders. Neurology 65(3): 499

Alberts JL, Okun MS, Vitek JL. 2008. The persistent effect of unilateral pallidal and subthalamic deep brain stimulation on force control in advanced Parkinson's patients. Parkinsonism and related disorders 14: 481488 
Alberts JL, Voelcker-Rehage C, Hallahan K, Vitek M, Bamzai R, Vitek JL. 2008. Bilateral subthalamic stimulation impairs cognitive-motor performance in Parkinson's disease patients. Brain 131: 3348-3360

Alegret M, Junqué C, Valldeoriola F, Vendrell P, Pilleri M, Rumià J, Tolosa E. 2001. Effects of Bilateral Subthalamic Stimulation on Cognitive Function in Parkinson Disease. Arch Neurol 58(8):1223-1227

Amirnovin R, Williams ZM, Cosgrove GR, Eskandar EN. 2006. Experience with microelectrode guided subthalamic nucleus deep brain stimulation. Neurosurgery 58 (suppl): S96-102.

Anderson VC, Burchiel KJ, Hogarth P, Favre J, Hammerstad JP. 2005. Pallidal vs Subthalamic Nucleus Deep Brain Stimulation in Parkinson Disease. Archives of Neurology 62(4): 554-560

Anheim M, Fraix V, Chabardès S, Krack P, Benabid AL, Pollak P. 2007. Lifetime of Itrel II pulse generators for subthalamic nucleusstimulation in Parkinson's disease. Mov Disord 22: 2436-39.

Anheim M, Batir A, Fraix V, Silem M, Chabardès S, Seigneuret E, Krack P, Benabid AL, Pollak P. 2008. Improvement in Parkinson Disease by Subthalamic Nucleus Stimulation Based on Electrode Placement. Effects of Reimplantation. Arch Neurol 65(5): 612-616

Arai N, Yokochi F, Ohnishi T, Momose T, Okiyama R, Taniguchi M, Takahashi H, Matsuda H, Ugawa Y. 2008. Mechanisms of unilateral STN-DBS in patients with Parkinson's disease. A PET study. Journal of Neurology 255: 1236-1243

Ardouin C, Pillon B, Peiffer E, Bejjani P, Limousin P, Damier P, Arnulf I, Benabid AL, Agid Y, Pollak P. 1999. Bilateral subthalamic or pallidal stimulation for Parkinson's disease affects neither memory nor executive functions: A consecutive series of 62 patients. Annals of Neurology 46(2): 217-223

Ardouin C, Voon V, Worbe Y, Abouazar N, Czernecki V, Hosseini H, Pelissolo A, Moro E, Lhommee E, Lang AE, Agid Y, Benabid A-L, Pollak P, Mallet L, Krack P. 2006. Pathological Gambling in Parkinson's Disease Improves on Chronic Subthalamic Nucleus Stimulation. Movement Disorders 21(11): 1941-1946

Arnulf I, Bejjani BP, Garma L, Bonnet AM, Houeto JL, Damier P, Derenne JP, Agid Y. 2000. Improvement of sleep architecture in PD with subthalamic nucleus stimulation. Neurology 55: 1732-35.

Aybek S, Gronchi-Perrin A, Berney A, Catalano Chiuvé S, Villemure J-G, Burkhard PR, Vingerhoets FJG. 2007. Long-term cognitive profile and incidence of dementia after STN-DBS in Parkinson's disease. Movement Disorders 22(7): 974-981

Ballanger B, van Eimeren T, Moro E, Lozano AM, Hamani C, Boulinguez P, Pellecchia G, Houle S, Poon YY, Lang AE, Strafella AP. 2009. Stimulation of the subthalamic nucleus and impulsivity: release your horses. Ann Neurol. 66(6): 817-24

Bannier S, Montaurier C, Derost PP, Ulla M, Lemaire J-J, Boirie Y, Morio B, Durif F . 2009. Overweight after deep brain stimulation of the subthalamic nucleus in Parkinson disease: long term follow-up. Journal of Neurology Neurosurgery and Psychiatry 80(5): 484-488

Bannier S, Montaurier C, Derost PP, Ulla M, Lemaire J-J, Boirie Y, Morio B, Durif F. 2008. Overweight after deep brain stimulatiuon of the subthalamic nucleus in Parkinson disease: long term follow up. $\mathrm{J}$ neurol neurosurg psychiatry 80: 484-488

Barichella M, Marczewska AM, Mariani C, Landi A, Vairo A, Pezzoli G. 2003. Body weight gain rate in patients with Parkinson's disease and deep brain stimulation. Movement Disorders 18(11): 1337-1340

Bastian AJ, Kelly VE, Revilla FJ, Perlmutter JS, Mink JW. . 2003. Different effects of unilateral versus bilateral subthalamic nucleus stimulation on walking and reaching in Parkinson's disease. . Mov Disord 18: 100007.

Bejjani BP, Dormont D, Pidoux B, Yelnik J, Damier P, Arnulf I, Bonnet A-M, Marsault C, Agid Y, Philippon J, Cornu P. 2000. Bilateral subthalamic stimulation for Parkinson's disease by using three-dimensional stereotactic magnetic resoonance imaging and electrophysiological guidance. J Neurosurg 92: 615-625

Bejjani B-P, Gervais D, Arnulf I, Papadopoulos S, Demeret S, Bonnet A-M, Cornu P, Damier P, Agid Y. 2000. Axial parkinsonian symptoms can be improved: the role of levodopa and bilateral subthalamic stimulation. J Neurol Neurosurg Psychiatry 68: 595-600

Benabid A-L, Koudsié A, Benazzouz A, Fraix V, Ashraf A, Le Bas JF, Chabardes S, Pollak P. 2000. Subthalamic stimulation for Parkinson's Disease. Archives of Medical Research 31: 282-289

Benabid AL, Krack P, Benazzouz A, Limousin P, Koudsie A, Pollak P. 2000. Deep brain stimulation of the subthalamic nucleus for Parkinson's disease: Methodologic aspects and clinical criteria. Neurology Volume 55(12) Supplement 6: S40-S44

Beric A, Kelly PJ, Rezai A, Sterio D, Mogilner A, Zonenshayn M, Kopell B. 2001. Complications of deep brain stimulation surgery. Stereotactic and Functional Neurosurgery 77(1-4): 73-78

Berney A, Panisset M, Sadikot AF, Ptito A, Dagher A, Fraraccio M, Savard G, Pell M, Benkelfat C. 2007. Mood stability during acute stimulator challenge in Parkinson's disease patients under long-term treatment with subthalamic deep brain stimulation. Movement Disorders 22(8): 1093-1096

Berney A, Vingerhoets F, Perrin A, Guex P, Villemure J-G, Burkhard PR, Benkelfat C, Ghika J. 2002. Effect on mood of subthalamic DBS for Parkinson's disease. A consecutive series of 24 patients. Neurology 59: 1427-1429

Binder DK, Rau GM, Starr PA. 2005. Risk factors for hemorrhage during microelectrode-guided deep brain stimulator implantation for movement disorders. Neurosurgery 56: 722-32. 
Biseul I, Sauleau P, Haegelen C, Trebon P, Drapier D, Raoul S, Drapier S, Lallement F, Rivier I, Lajat Y, Verin M. 2005. Fear recognition is impaired by subthalamic nucleus stimulation in Parkinson's disease. Neuropsychologia 43(7): 1054-1059

Blomstedt P, Hariz MI. 2006. Are Complications Less Common in Deep Brain Stimulation than in Ablative Procedures for Movement Disorders? Stereotact Funct Neurosurg 84: 72-81

Blomstedt P, Hariz MI. 2005. Hardware-related complications of deep brain stimulation: a ten year experience. . Acta Neurochir (Wien) 147: 1061-64.

Bordini BJ, Garg A, Gallagher CL, Bell B, Garell PC. 2007. Neuropsychological effects of bilateral deep brain stimulation of the subthalamic nucleus in Parkinson's disease. Stereotactic and Functional Neurosurgery 85(2-3): 113-120

Broggi G, Franzini A, Ferroli P, Servello D, D'Incerti L, Genitrini S, Soliveri P, Girotti F, Caraceni T. 2001. Effect of bilateral subthalamic electrical stimulation in Parkinson's disease. Surg. Neurol. 56(2): 89-94

Brown RG, Dowsey PL, Brown P, Jahanshahi M, Pollak P, Benabid AL, Rodriguez-Oroz MC, Obeso J, Rothwell JC. . 1999. Impact of deep brain stimulation on upper limb akinesia in Parkinson's disease. Ann Neurol. 45(4):473-88

Brusa L, Pierantozzi M, Peppe A, Altibrandi MG, Giacomini P, Mazzone P, Stanzione P. 2001. Deep brain stimulation (DBS) attentional effects parallel those of l-dopa treatment. J Neural Transm 108(8-9): 10211027

Burchiel KJ, Anderson VC, Favre J, Hammerstad JP. 1999. Comparison of pallidal and subthalamic nucleus deep brain stimulation for advanced Parkinson's disease: Results of a randomized, blinded pilot study. Neurosurgery 45(6): 1375-1382

Burkhard PR, Vingerhoets FJG, Berney A, Bogousslavsky J, Villemure J-G, Ghika J. 2004. Suicide after successful deep brain stimulation for movement disorders. Neurology 63: 2170-2172

Cantiniaux S, Vaugoyeau M, Robert D, Horrelou-Pitek C, Mancini J, Witjas T, Azulay JP. 2009. Comparative analysis of gait and speech in Parkinson's disease: hypokinetic or dysrhythmic disorders? J Neurol Neurosurg Psychiatry. 81(2):177-84

Capecci M, Ricciuti RA, Burini D, Bombace VG, Provinciali L, Iacoangeli M, Scerrati M, Ceravolo MG. 2005. Functional improvement after subthalamic stimulation in Parkinson's disease: a non-equivalent controlled study with 12-24 month follow up. Journal of Neurology, Neurosurgery \& Psychiatry 76(6): 769-74

Capus L, Melatini A, Zorzon M, Torre P, Carraro N, Moretti D, Gioulis M, Moretti R, Sarra MV, Marsala SZ. . 2001. Chronic bilateral electrical stimulation of the subthalamic nucleus for the treatment of advanced Parkinson's disease. Neurol Sci 22(1): 57-8.

Casamitjana CFP, García S, Méndez AZ, Salazar MH, Suárez SS, Dávalos EM, Ortiz CG, Venegas JB, Granados FJV, Cervantes JH, Luna OM, Vázquez AG, Blanco JV, Salazar AM, Sosa A, Álvarez NIP, Cerdeira EO, Cosmes JJ. 2007. Quality of life in patients with Parkinson's disease and deep-brainstimulation. Medicina Interna de Mexico 23(1): 7-14

Castelli L, Lanotte M, Ziberti M, Caglio M, Rizzi L, Ducati A, Bergamasco B, Lopiano L . 2007. Apathy and verbal fluency in STN-stimulated PD patients: An observational follow-up study. Journal of Neurology J. Neurol. 254(9): 1238-1243

Castelli L, Perozzo P, Genesia ML, Torre E, Pesare M, Cinquepalmi A, Lanotte M, Bergamasco B, Lopiano L. 2004. Sexual well being in parkinsonian patients after deep brain stimulation of the subthalamic nucleus. J Neurol Neurosurg Psychiatry 75: 1260-1264

Castelli L, Perozzo P, Zibetti M, Crivelli B, Morabito U, Lanotte M, Cossa F, Bergamasco B, Lopiano L. 2006. Chronic Deep Brain Stimulation of the Subthalamic Nucleus for Parkinson's Disease: Effects on Cognition, Mood, Anxiety and Personality Traits. Eur Neurol 55: 136-144

Castelli L, Rizzi L, Zibetti M, Angrisano S, Lanotte M, Lopiano L. 2009. Neuropsychological changes 1-year after subthalamic DBS in PD patients: A prospective controlled study. Parkinsonism Relat Disord. 16(2): $115-118$

Castelli L, Zibetti M, Rizzi L, Caglio M, Lanotte M, Lopiano L. 2008. Neuropsychiatric symptoms three years after subthalamic DBS in PD patients. A case-control study. J Neurol 255: 1515-1520

Castner Joanna E, Chenery Helen J, Copland David A, Coyne Terry J, Sinclair Felicity, Silburn Peter A. 2007. Semantic and affective priming as a function of stimulation of the subthalamic nucleus in Parkinson's disease. Brain 130, 1395-1407

Ceballos-Baumann AO, Boecker H, Bartenstein P, von Falkenhayn I, Riescher H, Conrad B, Moringlane JR, Alesch F. 1999. A positron emission tomographic study of subthalamic nucleus stimulation in Parkinson disease: enhanced movement-related activity of motor-association cortex and decreased motor cortex resting activity. Arch Neurol. 56(8): 997-1003.

Charles PD, Van Blercom N, Krack P, Lee SL, Xie J, Besson G, Benabid A-L, Pollak P. 2002. Predictors of effective bilateral subthalamic nucleus stimulation for PD. Neurology 59: 932-934

Chen CC, Lee ST, Wu T, Chen CJ, Chen MC, Lu CS. 2003. Short-term effect of bilateral subthalamic stimulation for advanced Parkinson's disease. Chang Gung Medical Journal 26(5): 344-351 
Chung SJ, Jeon SR, Kum SR, Sung YH, Lee MC. 2006. Bilateral effects of unilateral subthalamic nucleus deep brain stimulation in advanced Parkinson's disease. Eur Neurol 56:127-132

Cicolin A, Lopiano L, Zibetti M, Torre E, Tavella A, Guastamacchia G, Terreni A, Makrydakis G, Fattori E, Lanotte MM, Bergamasco B, Mutani R. 2004. Effects of deep brain stimulation of the subthalamic nucleus on sleep architecture in parkinsonian patients. Sleep Med. 5(2):207-10

Cilia R, Siri C, Marotta G, De Gaspari D, Landi A, Mariani CB, Benti R, Isaias IU, Vergani F, Pezzoli G, Antonini A. 2007. Brain networks underlining verbal fluency decline during STN-DBS in Parkinson's disease: An ECD-SPECT study. Parkinsonism and Related Disorders 13 (2007) 290-294

Colnat-Coulbois S, Gauchard GC, Maillard L, Barroche G, Vespignani H, Auque J, Perrin PP. 2005. Bilateral subthalamic nucleus stimulation improves balance control in Parkinson's disease. Journal of Neurology, Neurosurgery \& Psychiatry 76(6): 780-7

Contarino MF, Daniele A, Sibilia AH, Romito LMA, Bentivoglio AR, Gainotti G, Albanese A. 2007. Cognitive outcome 5 years after bilateral chronic stimulation of subthalamic nucleus in patients with Parkinson's disease. Journal of Neurology, Neurosurgery \& Psychiatry 78(3): 248-52

Crenna P, Carpinella I, Rabuffetti M, Rizzone M, Lopiano L, Lanotte M, Ferrarin M. 2006. Impact of subthalamic nucleus stimulation on the initiation of gait in Parkinson's disease. Exp Brain Res 172: 519532

Czernecki V, Pillon B, Houeto JL, Welter ML, Mesnage V, Agid Y, Dubois B. 2005. Does bilateral stimulation of the subthalamic nucleus aggravate apathy in Parkinson's disease?. Journal of Neurology, Neurosurgery \& Psychiatry 76(6): 775-9

Daniele A, Albanese A, Contarino M F, Zinzi P, Barbier A, Gasparini F, Romito L M A, Bentivoglio A R, Scerrati M . 2003. Cognitive and behavioural effects of chronic stimulation of the subthalamic nucleus in patients with Parkinson's disease. J Neurol Neurosurg Psychiatry 74: 175-182

De Gaspari D, Siri C, Di Gioia M, Antonini A, Isella C, Pizzolato A, Landi A, Vergani F, Gaini SM, Appollonio IM, Pezzoli G. 2006. Clinical correlates and cognitive underpinnings of verbal fluency impairment after chronic subthalamic stimulation in Parkinson's disease. Parkinsonism and Related Disorders 12: 289-295

De Gaspari D, Siri C, Landi A, Cili R, Bonetti A, Natuzzi F, Morgante L, Mariani CB, Sganzerla E, Pezzoli G, Antonini A. 2006. Clinical and neuropsychological follow up at 12 months in patients with complicated Parkinson's disease treated with subcutaneous apomorphine infusion or deep brain stimulation of the subthalamic nucleus. J Neurol Neurosurg Psychiatry 77: 450-453

Deep-Brain Stimulation for Parkinson's Disease Study Group . 2001. Deep-brain stimulation of the subthalamic nucleus or the pars interna of the globus pallidus in Parkinson's disease. New England Journal of Medicine 345(13): 956-63

Denheyer M, Kiss ZH, Haffenden AM. 2009. Behavioral effects of subthalamic deep brain stimulation in Parkinson's disease. Neuropsychologia 47(14):3203-9

Derost P-P, Ouchchane L, Morand D, Ulla M, Llorca P-M, Barget M, Debilly B, Lemaire J-J, Durif F. 2007. Is DBS-STN appropriate to treat severe Parkinson disease in an elderly population? Neurology 68(17): $1345-1355$

Deuschl G, Franke S. 2007. Deep brain stimulation in the therapy of advanced Parkinson's disease. Nervenheilkunde 26(4): 251-+

Deuschl G, Schade-Brittinger C, Krack P, Volkmann J, Schäfer H, Bötzel K, Daniels C, Deutschländer A, Dillmann U, Eisner W, Gruber D, Hamel W, Herzog J, Hilker R, Klebe S, Klo M, Koy J, Krause M, Kupsch A, Lorenz D, Lorenzl S, Mehdorn HM, Moringlane JR, Oertel W, Pinsker MO, Reichmann R, Reu A, Schneider G-H, Schnitzler A, Steude U, Sturm V, Timmermann L, Tronnier V, Trottenberg T, Wojtecki L, Wolf E, Poewe W, Voges J. 2006. A Randomized Trial of Deep-Brain Stimulation for Parkinson's Disease. N Engl J Med 355: 896-908.

Doshi PK, Chhaya NA, Bhatt MH. 2003. Bilateral subthalamic nucleus stimulation for Parkinson's disease. Neurology India 51(1): 43-48

Drapier D, Drapier S, Sauleau P, Haegelen C, Raoul S, Biseul I, Peron J, Lallement F, Rivier I, Reymann JM, Edan G, Verin M, Millet B. 2006. Does subthalamic nucleus stimulation induce apathy in Parkinson's disease?. J Neurol 253: 1083-1091

Drapier D, Peron J, Lerayc E, Sauleau P, Biseul I, Drapier S, Le Jeune F, Travers D, Bourguignon A, Haegelen C, Millet B, Verin M. 2008. Emotion recognition impairment and apathy after subthalamic nucleus stimulation in Parkinson's disease have separate neural substrates. Neuropsychologia 46 : 2796-2801

Drapier S, Raoul S, Drapier D, Leray E, Lallement F, Rivier I, Sauleau P, Lajat Y, Edan G, Vérin M. 2005. Only physical aspects of quality of life are significantly improved by bilateral subthalamic stimulation in Parkinson's disease. Journal of Neurology 252(5): 583-588

Dromey C, Kumar R, Lang AE, Lonzano AM. 2000. An investigation of the effects of subthalamic nucleus stimulation on acoustic measures of voice. Movement disorders 15(6): 1132-1138

Dujardin K, Blairy S, Defebvre L, Krystkowiak P, Hess U, Blond S, Destee A. 2004. Subthalamic nucleus stimulation induces deficits in decoding emotional facial expressions in Parkinson's disease. J Neurol Neurosurg Psychiatry 75: 202-208 
Dujardin K, Defebvre L, Krystkowiak P, Blond S, Destée A. 2001. Influence of chronic bilateral stimulation of the subthalamic nucleus on cognitive function in Parkinson's disease. Journal of Neurology 248(7): 603611

Ellis Tina-Marie, Foote Kelly D, Fernandez Hubert H, Sudhyadhom Atchar, Rodriguez Ramon L, Zeilman Pamela, Jacobson IV Charles E, Okun Michael S. 2008. Reoperation of suboptimal outcomes after deep brain stimulation surgery. Neurosurgery 63: 754-761

Erola T. 2006. Deep brain stimulation of the subthalamic nucleus in Parkinson's disease. Dissertation

Erola T, Heikkinen ER, Haapaniemi T, Tuominen J, Juolasmaa A, Myllyla VV. 2006. Efficacy of bilateral subthalamic nucleus (STN) stimulation in Parkinson's disease. Acta Neurochir (Wien) 148: 389-394

Erola T, Karinen P, Heikkinen E, Tuiminen J, Haapaniemi T, Myllylä V, Koivukangas J. 2006. Bilateral subthalamic nucleus deep brain stimulation: the direct costs compared to the effects. Annals in Neurosurgery 6(1): 1-7

Erola T, Karinen P, Heikkinen E, Tuominen J, Haapaniemi T, Koivukangas J, Myllylä V. 2005. Bilateral subthalamic nucleus stimulation improves health-related quality of life in Parkinsonian patients. Parkinsonism \& Related Disorders 11(2): 89-94

Eskandart EN, Flaherty A, Cosgrove GR, Shinobu LA, Barker FG. 2003. Surgery for Parkinson disease in the United States, 1996 to 2000: practice patterns, short-term outcomes, and hospital charges in a nationwide sample. Journal of Neurosurgery 99(5): 863-871

Esselink RAJ, de Bie RMA, de Haan RJ, Lenders MWPM, Nijssen PCG, Staal MJ, Smeding HMM, Schuurman PR, Bosch DA, Speelman JD. 2004. Unilateral pallidotomy versus bilateral subthalamic nucleus stimulation in PD. A randomized trial. Neurology 62: 201-207

Esselink RAJ, de Bie RMA, de Haan RJ, Steur ENHJ, Beute GN, Portman AT, Schuurman PR, Bosch DA, Speelman JD. 2006. Unilateral pallidotomy versus bilateral subthalamic nucleus stimulation in Parkinson's disease: one year follow-up of a randomised observer-blind multi centre trial. Acta Neurochir (Wien) 148: 1247-1255

Faist M, Xie J, Kurz D, Berger W, Maurer C, Pollak P, Lücking CH. 2001. Effect of bilateral subthalamic nucleus stimulation on gait in Parkinson's disease. Brain 124: 1590-1600

Ferrara J, Diamond A, Hunter C, Davidson A, Almaguer M, Jankovic J. 2009. Impact of STN-DBS on life and health satisfaction in patients with Parkinson's disease. J Neurol Neurosurg Psychiatry 81(3): 315-9. Epub 2009

Ferrarin M, Rizzone M, Bergamasco B, Lanotte M, Recalcati M, Pedotti A, Lopiano L. 2005. Effects of bilateral subthalamic stimulation on gait kinematics and kinetics in Parkinson's disease. Exp Brain Res 160: 517527

Figueiras-Méndez R, Regidor I, Riva-Meana C, Magariños-Ascone CM. 2002. Further supporting evidence of beneficial subthalamic stimulation in Parkinson's patients. Neurology 58: 469-500

Fimm B, Heber IA, Coenen VA, Fromm C, Noth J, Kronenbuerger M. 2009. Deep brain stimulation of the subthalamic nucleus improves intrinsic alertness in Parkinson's disease. Mov Disord. 24(11):1613-20.

Finazzi-Agro E, Peppe A, D’Amico A, Petta F, Mazzone P, Stanzione P, Micali F, Caltagirone C. 2003. Effects of subthalamicnucleus stimulation on urodynamic findings in patients with Parkinson's disease. J Urol 169: 1388-91.

Foffani G, Ardolino G, Egidi M, Caputo E, Bossi B, Priori A. 2006. Subthalamic oscillatory activities at beta or higher frequency do not change after high-frequency DBS in Parkinson's disease. Brain Research Bulletin $69,123-130$

Ford B, Winfield L, Pullman SL, Frucht SJ, Du Y, Greene P, Cheringal JH, Yu Q, Cote LJ, Fahn S, McKhann II GM, Goodman RR. 2004. Subthalamic nucleus stimulation in advanced Parkinson's disease: blinded assessments at one year follow up. J Neurol Neurosurg Psychiatry 75: 1255-1259

Fraix V, Houeto J-L, Lagrange C, Le Pen C, Krystkowiak P, Guehl D, Ardouin C, Welter M-L, Maurel F, Defebvre L, Rougier A, Benabid A-L, Mesnage V, Ligier M, Blond S, Burbaud P, Bioulac B, Destee A, Cornu P, Pollak P. 2006. Clinical and economic results of bilateral subthalamic nucleus stimulation in Parkinson's disease. J Neurol Neurosurg Psychiatry 77: 443-449

Fraix V, Pollak P, Moro E, Chabardes S, Xie J, Ardouin C, Benabid AL. 2005. Subthalamic nucleus stimulation in tremor dominant parkinsonian patients with previous thalamic surgery. Journal of Neurology Neurosurgery and Psychiatry 76(2): 246-248

Fraix V, Pollak P, Van Blercom N, Xie J, Krack P, Koudsie A, Benabid AL. 2000. Effect of subthalamic nucleus stimulation on levodopa-induced dyskinesia in Parkinson's disease. Neurology 55: 1921-1923

Frank MJ, Samanta J, Moustafa AA, Sherman SJ. 2007. Hold your horses: Impulsivity, deep brain stimulation, and medication in Parkinsonism. Science 318(5854): 1309-1312

Fraraccio M, Ptito A, Sadikot A, Panisset M, Dagher A. 2008. Absence of cognitive deficits following deep brain stimulation of the subthalamic nucleus for the treatment of Parkinson's disease. Archives of Clinical Neuropsychology 23: 399-408 
Funkiewiez A, Ardouin C, Caputo E, Krack P, Fraix V, Klinger H, Chabardes S, Foote K, Benabid A-L, Pollak P. 2004. Long term effects of bilateral subthalamic nucleus stimulation on cognitive function, mood, and behaviour in Parkinson's disease. J Neurol Neurosurg Psychiatry 75: 834-839

Funkiewiez A, Ardouin C, Cools R, Krack P, Fraix V, Batir A, Chabardes S, Benabid A-L, Robbins TW, Pollak P. 2006. Effects of Levodopa and Subthalamic Nucleus Stimulation on Cognitive and Affective Functioning in Parkinson's Disease. Movement Disorders 21(10): 1656-1662

Funkiewiez A, Ardouin C, Krack P, Fraix V, Van Blercom N, Xie J, Moro E, Benabid A-L, Pollak P. 2003. Acute psychotropic effects of bilateral subthalamic nucleus stimulation and levodopa in Parkinson's disease. Movement Disorders 18(5): 524-530

Gan J, Xie-Brustolin J, Mertens P, Polo G, Klinger H, Mollion H, Benatru I, Henry E, Broussolle E, Thobois S. 2007. Bilateral subthalamic nucleus stimulation in advanced Parkinson's disease: Three years follow-up. Journal of Neurology J. Neurol. 254(1): 99-106

Geday J, Ostergaard K, Gjedde A. 2006. Stimulation of subthalamic nucleus inhibits emotional activation of fusiform gyrus. NeuroImage 33: 706-714

Gentil M, Chauvin P, Pinto S, Pollak P, Benabid AL. 2001. Effect of bilateral stimulation of the subthalamic nucleus on parkinsonian voice. Brain Lang 78(2):233-40.

Gentil M, Garcia-Ruiz P, Pollak P, Benabid AL . 2000. Effect of Bilateral Deep-Brain Stimulation on Oral Control of Patients with Parkinsonism. Eur Neurol 44: 147-152

Gentil M, Garcia-Ruiz P, Pollak P, Benabid AL. 1999. Effect of stimulation of the subthalamic nucleus on oral control of patients with parkinsonism. J Neurol Neurosurg Psychiatry 67(3):329-33

Gentil M, Pinto S, Pollak P, Benabid AL. 2003. Effect of bilateral stimulation of the subthalamic nucleus on parkinsonian dysarthria. Brain Lang 85: 190-96.

Germano IM, Gracies J-M, Weisz DJ, Tse T, Koller WC, Olanow CW. 2004. Unilateral stimulation of the subthalamic nucleus in Parkinson disease: a double-blind 12-month evaluation study. J Neurosurg $101: 36-42,2004$

Gervais-Bernard H, Xie-Brustolin J, Mertens P, Polo G, Klinger H, Adamec D, Broussolle E, Thobois S. 2009. Bilateral subthalamic nucleus stimulation in advanced Parkinson's disease: Five year follow-up. Journal of Neurology 256(2): 225-233

Gill Chandler E, Konrad Peter E, Davis Thomas L, Charles David. 2007. Deep brain stimulation for Parkinson's disease: the Vanderbilt University Medical Center experience, 1998-2004 . Tennessee medicine : journal of the Tennessee Medical Association. Tenn Med 100(4): 45-47.

Gironell A, Kulisevsky J, Rami L, García-Sánchez NFC, Pascual-Sedano B. 2003. Effects of pallidotomy and bilateral subthalamic stimulation on cognitive function in Parkinson disease. J Neurol 250 : 917-923

Gisquet Elsa. 2008. Cerebral implants and Parkinson's disease: A unique form of biographical disruption?. Social Science \& Medicine 67: 1847-1851

Gómez-Esteban Juan C, Lezcano Elena, Zarranz Juan J, González Carmen, Bilbao Gaizka, Lambarri Imanol, Garibi Jesús. 2008. Outcome of bilateral deep brain stimulation in patients carrying the R1441G mutation in the LRRK2 dardarin gene. Neurosurgery 62:857-863, 2008

Goodman RR, Kim B, McClelland III S, Senatus PB, Winfield LM, Pullman SL, Yu Q, Ford B, McKhann II GM. 2006. Operative techniques and morbidity with subthalamic nucleus deep brain stimulation in 100 consecutive patients with advanced Parkinson's disease. J Neurol Neurosurg Psychiatry 77: 12-17

Gorgulho A, De Salles AA, Frighetto L, Behnke E. . 2005. Incidence of hemorrhage associated with electrophysiological studies performedusing macroelectrodes and microelectrodes in functionalneurosurgery. . J Neurosurg 102: 888-96.

Gronchi-Perrin A, Viollier S, Ghika J, Combremont P, Villemure J-G, Bogousslavsky J, Burkhard PR, Vingerhoets F. 2006. Does Subthalamic Nucleus Deep Brain Stimulation Really Improve Quality of Life in Parkinson's Disease? Movement Disorders 21(9): 1465-1468

Guehl D, Cuny E, Benazzouz A, Rougier A, Tison F, Machado S, Grabot D, Gross C, Bioulac B, Burbaud P. 2006. Side-effects of subthalamic stimulation in Parkinson's disease: clinical evolution and predictive factors. European Journal of Neurology 2006, 13: 963-971

Guo X, Gao G, Wang X, Li, L, Li W, Liang Q, Zhang H. 2008. Effects of bilateral deep brain stimulation of the subthalamic nucleus on olfactory function in parkinson's disease patients. Stereotact Funct Neurosurg 86: 237-244

Haegelen C, García-Lorenzo D, Le Jeune F, Péron J, Gibaud B, Riffaud L, Brassier G, Barillot C, Vérin M, Morandi X. 2009. SPECT and PET analysis of subthalamic stimulation in Parkinson's disease: analysis using a manual segmentation. J Neurol 257(3): 375-82. Epub 2009

Haegelen C, Verin M, Aubert Broche B, Prigent F, Jannin P, Gibaud B, Morandi X. 2005. Does subthalamic nucleus stimulation affect the frontal limbic areas? A single-photon emission computed tomography study using a manual anatomical segmentation method. Surg Radiol Anat 27: 389-394

Hälbig TD, Gruber D, Kopp UA, Scherer P, Schneider G-H, Trottenberg T, Arnold G, Kupsch A. 2004. Subthalamic stimulation di $;$ erentially modulates declarative and nondeclarative memory. Neuroreport 15(3): 539-543 
Hälbig TD, Tse W, Frisina PG, Baker BR, Hollander E, Shapiro H, Tagliati M, Koller WC, Olanow CW. 2009. Subthalamic deep brain stimulation and impulse control in Parkinson's disease. european Journal of Neurology 16: 493-497

Hariz GM, Lindberg M, Hariz MI, Bergenheim AT . 2003. Gender differences in disability and health-related quality of life in patients with Parkinson's disease treated with stereotactic surgery. Acta Neurologica Scandinavica 108(1): 28-37

Hariz MI, Rehncrona S, Quinn NP, Speelman JD, Wensing C, and the Multicentre Advanced Parkinson's Disease Deep Brain Stimulation Group. 2008. Multicenter Study on Deep Brain Stimulation in Parkinson's Disease: An Independent Assessment of Reported Adverse Events at 4 Years. Movement Disorders 23(3): 416-421

Hausdorff JM, Gruendlinger L, Scollins L, O'Herron S, Tarsy D. 2009. Deep brain stimulation effects on gait variability in Parkinson's disease. Mov Disord 24(11): 1688-92.

Heo Jae-Hyeok, Lee Kyoung-Min, Paek Sun Ha, Kim Min-Jeong, Lee Jee-Young, Kim Ji-Young, Cho SooYoung, Lim Yong Hoon, Kim Mi-Ryoung, Jeong Soo Yeon, Jeon Beom S. 2008. The effects of bilateral Subthalamic Nucleus Deep Brain Stimulation (STN DBS) on cognition in Parkinson disease. Journal of the Neurological Sciences 273: 19-24

Hershey T, Revilla FJ, Wernle A, Schneider Gibson P, Dowling JL, Perlmutter JS. 2004. Stimulation of STN impairs aspects of cognitive control in PD. Neurology 62: 1110-1114

Hershey T, Revilla FJ, Wernle AR, McGee-Minnich L, Antenor JV, Videen TO, Dowling JL, Mink JW, Perlmutter JS. 2003. Cortical and subcortical blood flow effects of subthalamic nucleus stimulation in PD. Neurology 61: 816-821

Hershey T, Wu J, Weaver PM, Perantie DC, Karimi M, Tabbal SD, Perlmutter JS. 2008. Unilateral vs. bilateral STN DBS effects on working memory and motor function in Parkinson disease. Experimental Neurology 210: 402-408

Herzog J, Volkmann J, Krack P, Kopper F, Pötter M, Lorenz D, Steinbach M, Klebe S, Hamel W, Schrader B, Weinert D, Müller D, Mehdorn HM, Deuschl G. 2003. Two-year follow-up of subthalamic deep brain stimulation in Parkinson's disease. Movement Disorders 18(11): 1332-1337

Higginson CI, Wheelock VL, Levine D, King DS, Pappas CTE, Sigvardt KA. 2009. The clinical significance of neuropsychological changes following bilateral subthalamic nucleus deep brain stimulation for Parkinson's disease. Journal of Clinical and Experimental Neuropsychology 31(1): 65-72

Hilker R, Portman AT, Voges J, Staal MJ, Burghaus L, van Laar T, Koulousakis A, Maguire RP, Pruim J, de Jong BM, Herholz K, Sturm V, Heiß W-D, Leenders KL. 2005. Disease progression continues in patients with advanced Parkinson's disease and effective subthalamic nucleus stimulation. Journal of Neurology, Neurosurgery and Psychiatry J. Neurol. Neurosurg. Psychiatry 76(9): 1217-1221

Hilker R, Voges J, Weber T, Kracht LW, Roggendorf J, Baudrexel S, Hoevels M, Sturm V, Heiss WD. 2008. STN-DBS activates the target area in parkinson disease. A FDG-PET study. Neurology 71: 708-713

Hilker R, Voges J, Weisenbach S, Kalbe E, Burghaus L, Ghaemi M, Lehrke R, Koulousakis A, Herholz K, Sturm V, Heiss W-D. 2004. Subthalamic nucleus stimulation restores glucose metabolism in associative and limibic cortices and in cerebellum: evidence from a FDG-PET study in advanced Parkinson's disease. Journal of cerebral blood flow \& metabolism 24(1): 7-16

Hilker R, Voges J, Weisenbach S, Kalbe E, Burghaus L, Ghaemi M, Lehrke R, Koulousakis A, Herholz K, Sturm V, Heiss W-D. 2003. Subthalamic Nucleus Stimulation Restores Glucose Metabolism in Associative and Limbic Cortices and in Cerebellum: Evidence from a FDG-PET Study in Advanced Parkinson's Disease. Journal of Cerebral Blood Flow \& Metabolism 24:7-16

Hjort N, Ostergaard K, Dupont E. 2004. Improvement of sleep quality inpatients with advanced Parkinson's disease treated with deep brainstimulation of the subthalamic nucleus. Mov Disord 19: 196-99.

Houeto JL, Damier P, Bejjani PB, Staedler C, Bonnet AM, Arnulf I, Pidoux B, Dormont D, Cornu P, Agid Y. 2000. Subthalamic Stimulation in Parkinson Disease. A Multidisciplinary Approach. Arch Neurol 57: 461-465

Houeto J-L, Mallet L, Mesnage V, du Montcel ST, Behar C, Gargiulo M, Torny F, Pelissolo A, Welter M-L, Agid Y. 2006. Subthalamic Stimulation in Parkinson Disease. Behavior and Social Adaptation. Arch Neurol 63: 1090-1095

Houeto JL, Mesnage V, Mallet L, Pillon B, Gargiulo M, Tezenas du Moncel S, Bonnet AM, Pidoux B, Dormont D, Cornu P, Agid Y. 2002. Behavioural disorders, Parkinson's disease and subthalamic stimulation. J Neurol Neurosurg Psychiatry 72: 701-707

Houeto JL, Mesnage V, Welter ML, Mallet L, Agid Y, Bejjani BP. 2003. Subthalamic DBS replaces levodopa in Parkinson's disease: two year follow up. Neurology 60: 154-55.

Hummel T, Jahnke U, Sommer U, Reichmann H, Müller A. 2005. Olfactory function in patients with idiopathic Parkinson's disease: effects of deep brain stimulation in the subthalamic nucleus. J Neural Transm. 112(5): 669-76

Iansek R, Rosenfeld JV, Huxham FE. 2002. Deep brain stimulation of the subthalamic nucleus in Parkinson's disease. MJA 177: 142-146 
Iranzo A, Valldeoriola F, Santamaria J, Tolosa E, Rumia J. 2002. Sleep symptoms and polysomnographic architecture in advanced Parkinson's disease after chronic bilateral subthalamic stimulation. J Neurol Suerosurg Psychiatry 72: 661-664

Israel Z, Hassin-Baer S. 2005. Subthalamic Stimulation for Parkinson's Disease. IMAJ 7: 458-463

Jaggi JL, Umemura A, Hurtig HI, Siderowf AD, Colcher A, Stern MB, Baltuch GH. 2004. Bilateral Stimulation of the Subthalamic Nucleus in Parkinson's Disease: Surgical Efficacy and Prediction of Outcome. Stereotact Funct Neurosurg 82: 104-114

Jahanshahi M, Ardouin CMA, Brown RG, Rothwell JC, Obeso J, Albanese A, Rodriquez-Oroz MC, Moro E, Benabid AL, Pollak P, Limousin-Dowsey P. 2000. The impact of deep brain stimulation on executive function in Parkinson's disease. Brain 123: 1142-1154

Joint C, Nandi D, Parkin S, Gregory R, Aziz T. 2002. Hardware-related problems of deep brain stimulation. Movement disorders 17(3): S175-S180

Just H, Ostergaard K. 2002. Health-Related Quality of Life in Patients with Advanced Parkinson's Disease Treated with Deep Brain Stimulation of the Subthalamic Nuclei. Movement Disorders 17(3): 539-545

Kalteis K, Standhardt H, Kryspin-Exner I, Brucke T, Volc D, Alesch F. 2006. Influence of bilateral Stnstimulation on psychiatric symptoms and psychosocial functioning in patients with Parkinson's disease. J Neural Transm 113: 1191-1206

Katayama Y, Kasai M, Oshima H, Fukaya C, Yamamoto T, Ogawa K, Mizutani T. 2001. Subthalamic nucleus stimulation for Parkinson disease: benefits observed in levodopa-intolerant patients. J Neurosurg 95(2): 213-221

Kenney C, Simpson R, Hunter C, Ondo W, Almaguer M, Davidson A, Jankovic J. 2007. Short-term and longterm safety of deep brain stimulation in the treatment of movement disorders. Journal of Neurosurgery 106(4): 621-625

Kleiner-Fisman G, Fisman D, Sime E, Saint-Cyr JA, Lozano AM, Lang AE. 2003. Long-term follow up of bilateral deep brain stimulation of the subthalamic nucleus in patients with advanced Parkinson disease. $\mathrm{J}$ Neurosurg 99:489-495

Kleiner-Fisman G, Fisman DN, Zamir O, Dostrovsky JO, Sime E, Saint-Cyr JA, Lozano AM, Lang AE. 2004. Subthalamic Nucleus Deep Brain Stimulation for Parkinson's Disease After Successful Pallidotomy: Clinical and Electrophysiological Observations. Movement Disorders 19(10): 1209-1214

Klempířová O, Jech R, Urgošík D, Klempír J, Špačková N, Roth J, Růžička E . 2007. Deep Brain Stimulation of the Subthalamic Nucleus and Cognitive Functions in Parkinson's Disease. Prague Medical Report 108(4): 315-323

Klostermann F, Ehlen F, Vesper J, Nubel K, Gross M, Marzinzik F, Curio G, Sappok T. 2008. Effects of subthalamic deep brain stimulation on dysarthrophonia in Parkinson's disease. J Neurol Neurosurg Psychiatry 79(5): 522-9

Koch G, Brusa L, Caltagiore C, Oliveri M, Peppe A, Tiraboschi P, Stanzione P. 2004. Subthalamic deep brain stimulation improves time perception in Parkinson's disease. NeuroReport 15(6): 1071-1073

Krack P, Batir A, Van Blercom N, Chabardes S, Fraix V, Ardouin C, Koudsie A, Dowsey Limousin P, Benazzouz A, LeBas JF, Benabid AL, Pollak P . 2003. Five-year follow-up of bilateral stimulation of the subthalamic nucleus in advanced Parkinson's disease. New England Journal of Medicine 349(20): 19251934

Krack P, Benazzouz A, Pollak P, Limousin P, Piallat B, Hoffmann D, Xie J, Benabid AL. 1998. Treatment of Tremor in Parkinson's Disease by Subthalamic Nucleus Stimulation. Movement Disorders 13(6): 907-914

Krack P, Limousin P, Benabid AL, Pollak P. 1997. Chronic stimulation of subthalamic nucleus improves levodopa-induced dyskinesias in Parkinson's disease. Lancet 350(9092): 1676

Krack P, Pollak P, Limousin P, Benazzouz A, Benabid AL. 1997. Stimulation of subthalamic nucleus alleviates tremor in Parkinson's disease. Lancet 350(9092): 1675

Krack P, Pollak P, Limousin P, Benazzouz A, Deuschl G, Benabid AL. 1999. From off-period dystonia to peakdose chorea. The clinical spectrum of varying subthalamic nucleus activity. Brain 122 (6): 1133-46.

Krack P, Pollak P, Limousin P, Hoffmann D, Xie J, Benazzouz A, Benabid AL. 1998. Subthalamic nucleus or internal pallidal stimulation in young onset Parkinson's disease. Brain 121: 451-457

Krause M, Fogel W, Heck A, Hacke W, Bonsanto M, Trenkwalder C, Tronnier V. 2001. Deep brain stimulation for the treatment of Parkinson's disease: subthalamic nucleus versus globus pallidus internus. Journal of Neurology Neurosurgery and Psychiatry 70(4): 464-470

Krause M, Fogel W, Mayer P, Kloss M, Tronnier V. 2004. Chronic inhibition of the subthalamic nucleus in Parkinson's disease. Journal of the Neurological Sciences 219: 119-124

Krystkowiak P, Blatt JL, Bourriez J-L, Duhamel A, Perina M, Blond S, Guieu J-D, Destée A, Defebvre L. 2003. Effects of Subthalamic Nucleus Stimulation and Levodopa Treatment on Gait Abnormalities in Parkinson Disease. Arch Neurol. 60(1):80-84.

Kühn AA, Hariz MI, Silberstein P, Tisch S, Kupsch A, Schneider G-H, Limousin-Dowsey P, Yarrow K, Brown P. 2005. Activation of the subthalamic region during emotional processing in Parkinson disease. Neurology 65: 707-713 
Kühn AA, Kempf F, Brücke C, Doyle LG, Martinez-Torres I, Pogosyan A, Trottenberg T, Kupsch A, Schneider G-H, Hariz MI, Vandenberghe W, Nuttin B, Brown P. 2008. High frequency stimulation of the subthalamic nucleus supresses oscillatory beta activity in patients with parkinson's disease in parallel with imrpvement in motor performance. The Journal of Neuroscience 28(24): 6165-6173

Kumar R, Lozano A, Sime E, Halket E, Lang AE. 1999. Comparative effects of unilateral and bilateral subthalamic nucleus deep brain stimulation. Neurology Volume 53(3), 11 August 1999, pp 561-566

Kumar R, Lozano AM, Kim YJ, Hutchison WD, Sime E, Halket E, Lang AE. 1998. Double-blind evaluation of subthalarnic nucleus deep brain stimulation in advanced Parkinson's disease. Neurology 51: 850-855

Kuriakose R, Saha U, Castillo G, Udupa K, Ni Z, Gunraj C, Mazzella F, Hamani C, Lang AE, Moro E, Lozano AM, Hodaie M, Chen R. 2009. The Nature and Time Course of Cortical Activation Following Subthalamic Stimulation in Parkinson's Disease. Cereb Cortex. 2009 Dec 17. [Epub ahead of print]

Lagrange E, Krack P, Moro E, Ardouin C, Van Blercom N, Chabardes S, Benabid AL, Pollak P. 2002. Bilateral subthalamic nucleus stimulation improves health-related quality of life in PD. Neurology 59: 1976-1978

Landi A, Parolin M, Piolti R, Antonini A, Grimaldi M, Crespi M, Iurlaro S, Aliprandi A, Pezzoli G, Ferrarese C, Gaini SM. 2003. Deep brain stimulation for the treatment of Parkinson's disease: The experience of the Neurosurgical Department in Monza. Neurological Sciences 24 (Suppl 1): S43-S44

Lanotte MM, Rizzone M, Bergamasco B, Faccani G, Melcarne A, Lopiano L. 2002. Deep brain stimulation of the subthalamic nucleus: anatomical, neurophysiological, and outcome correlations with the effects of stimulation. J Neurol Neurosurg Psychiatry 72: 53-58

Le Jeune F, Drapier D, Bourguignon A, Péron J, Mesbah H, Drapier S, Sauleau P, Haegelen C, Travers D, Garin E, Malbert CH, Millet B, Vérin M. 2009. Subthalamic nucleus stimulation in Parkinson disease induces apathy: a PET study. Neurology 73(21): 1746-51.

Le Jeune F, Péron J, Biseul I, Fournier S, Sauleau P, Drapier S, Haegelen C, Drapier D, Millet B, Garin E, Herry J-Y, Malbert C-H, Vérin M. 2008. Subthalamic nucleus stimulation affects orbitofrontal cortex in facial emotion recognition: a PET study. Brain 131: 1599-1608

Lee Ji Yeoun, Han Jung Ho, Kim Han Joon, Jeon Beom Seok, Kim Dong Gyu, Paek Sun Ha. 2008. STN DBS of Advanced Parkinson's Disease Experienced in a Specialized Monitoring Unit with a Prospective Protocol. J Korean Neurosurg Soc 44 : 26-35, 2008

Lee JY, Jeon BS, Paek SH, Lim YH, Kim MR, Kim C. 2009. Reprogramming guided by the fused images of MRI and CT in subthalamic nucleus stimulation in Parkinson disease. Clin Neurol Neurosurg 112(1): 4753

Lefaucheur J-P, Gurruchaga J-M, Pollin B, von Raison F, Mohsen N, Shin M, Ménard-Lefaucheur I, Oshino S, Kishima H, Fénelon G, Rémy P, Cesaro P, Gabriel I, Brugières P, Keravel Y, Nguyen J-P. 2008. Outcome of Bilateral Subthalamic Nucleus Stimulation in the Treatment of Parkinson's Disease: Correlation with Intra-Operative Multi-Unit Recordings but Not with the Type of Anaesthesia. Eur Neurol 60: 186-199

Lévesque MF, Taylor S, Rogers R, Le MT, Swope D. 1999. Subthalamic stimulation in Parkinson's disease. Preliminary results. Movement Disorders 72: 170-173

Lezcano E, Gomez-Esteban JC, Zarranz JJ, Lambarri I, Madoz P, Bilbao G, Pomposo I, Garibi J. 2004. Improvement in quality of life in patients with advanced Parkinson's disease following bilateral deepbrain stimulation in subthalamic nucleus. European Journal of Neurology 2004, 11: 451-454

Liang GS, Chou KL, Baltuch GH, Jaggi JL, Loveland-Jones C, Leng L, Maccarone H, Hurtig HI, Colcher A, Stern MB, Kleiner-Fisman G, Simuni T, Siderowf AD. 2006. Long-Term Outcomes of Bilateral Subthalamic Nucleus Stimulation in Patients with Advanced Parkinson's Disease. Stereotact Funct Neurosurg 84: 221-227

Lim SY, O'Sullivan SS, Kotschet K, Gallagher DA, Lacey C, Lawrence AD, Lees AJ, O'Sullivan DJ, Peppard RF, Rodrigues JP, Schrag A, Silberstein P, Tisch S, Evans AH. 2009. Dopamine dysregulation syndrome, impulse control disorders and punding after deep brain stimulation surgery for Parkinson's disease. J Clin Neurosci. 16(9): 1148-52

Limousin P, Greene J, Pollak P, Rothwell J, Benabid A-L, Frackowiak R. 1997. Changes in Cerebral Activity Pattern Due to Subthalamic Nucleus or Internal Pallidum Stimulation in Parkinson's Disease. Annals of Neurology 42(3):283-291

Limousin P, Krack P, Pollak P, Benazzouz A, Ardouin C, Hoffmann D, Benabid A-L. 1998. Electrcal stimulation of the subthalamic nucleus in advanced Parkinson's Disease. Lancet 339(16): 1105-1111

Limousin P, Pollak P, Benazzouz A, Hoffmann D, Le Bas JF, Broussolle E, Perret JE, Benabid AL. 1995. Effect on parkinsonian signs and symptoms of bilateral subthalamic nucleus stimulation. Lancet 345(8942):91-5.

Linazasoro G. 2003. Subthalamic deep brain stimulation for advanced Parkinson's disease: All that glitters is not gold. Journal of Neurology, Neurosurgery \& Psychiatry 74(6): 827

Liu W, McIntire K, Kim SH, Zhang J, Dascalos S, Lyons KE, Pahwa R. 2006. Bilateral subthalamic stimulation improves gait initiation in patients with Parkinson's disease. Gait \& Posture 23: 492-498

Lopiano L, Rizzone M, Bergamasco B, Tavella A, Torre E, Perozzo P, Lanotte M. 2002. Deep brain stimulation of the subthalamic nucleus in PD: an analysis of the exclusion causes. Journal of the Neurological Sciences 195: 167- 170 
Lopiano L, Rizzone M, Bergamasco B, Tavella A, Torre E, Perozzo P, Valentini MC, Lanotte M. 2001. Deep brain stimulation of the subthalamic nucleus: Clinical effectiveness and safety. Neurology 56(4): 552-554

Lu C, Bharmal A, Suchowersky O. 2006. Gambling and Parkinson Disease. Arch Neurol 63: 298

Ludwig J, Remien P, Guballa C, Binder A, Binder S, Schattschneider J, Herzog J, Volkmann J, Deuschl G, Wasner G, Baron R. 2007. Effects of subthalamic nucleus stimulation and levodopa on the autonomic nervous system in Parkinson's disease. Journal of Neurology, Neurosurgery \& Psychiatry 78(7): 742-5

Lueke Ulrike, Schwarz Michaela, Hertel Frank, Schweiger Elisabeth, Wittling Werner. 2008. Impaired performance on the Wisconsin Card Sorting Test under left- when compared to right-sided deep brain stimulation of the subthalamic nucleus in patients with Parkinson's disease. J Neurol 255:1940-1948

Lyons KE, Davis JT, Pahwa R. 2007. Subthalamic nucleus stimulation in Parkinson's disease patients intolerant to levodopa. Stereotactic and Functional Neurosurgery 85(4): 169-174

Lyons KE, Koller WC, Wilkinson SB. 2001. Long term safety and efficacy of unilateral deep brain stimulation of the thalamus for parkinsonian tremor. Journal of Neurology, Neurosurgery \& Psychiatry 71(5): 682684

Lyons KE, Pahwa R. 2005. Long-term benefits in quality of life provided by bilateral subthalamic stimulation in patients with Parkinson disease. Journal of Neurosurgery 103(2): 252-255

Lyons KE, Wilkinson SB, Overman J, Pahwa R. . 2004. Surgical andhardware complications of subthalamic stimulation: a series of 160 procedures. . Neurology 63: 612-16.

Macia F, Perlemoine C, Coman I, Guehl D, Burbaud P, Cuny E, Gin H, Rigalleau V, Tison F. 2004. Parkinson's disease patientswith bilateral subthalamic deep brain stimulation gain weight. Mov Disord 19: 206-12.

Martínez-Martín P, Valldeoriola F, Tolosa E, Pilleri M, Molinuevo JL, Rumià J, Ferrer E. 2002. Bilateral Subthalamic Nucleus Stimulation and Quality of Life in Advanced Parkinson's Disease. Movement Disorders 17(2): 372-377

Meissner W, Schreiter D, Volkmann J, Trottenberg T, Schneider GH, Sturm V, Deuschl G, Kupsch A. 2005. Deep brain stimulation in late stage Parkinson's disease: a retrospective cost analysis in Germany. J Neurol 252(2):218-23.

Merello M, Tenca S, Perez Lloret S, Martin ME, Bruno V, Cavanagh S, Antico J, Cerquetti D, Leiguarda R. 2008. Prospective randomized 1-year follow-up comparison of bilateral subthalamotomy versus bilateral subthalamic stimulation and the combination of both in Parkinson's disease patients: a pilot study. British Journal of Neurosurgery 22(3): 415-422

Mikos A, Zahodne L, Okun MS, Foote K, Bowers D. 2009. Cognitive declines after unilateral deep brain stimulation surgery in Parkinson's disease: a controlled study using Reliable Change, part II. Clin Neuropsychol 24(2): 235-45

Minguez-Castellanos A, Escamilla-Sevilla F, Katati MJ, Martin-Linares JM, Meersmans M, Ortega-Moreno A, Arjona V. 2005. Different patterns of medication change after subthalamic or pallidal stimulation for Parkinson's disease: target related effect or selection bias?. J Neurol Neurosurg Psychiatry 76:34-39

Molinuevo JL, Valldeoriola F, Tolosa E, Rumia J, Valls-Sole J, Roldan H, Ferrer E. 2000. Levodopa Withdrawal After Bilateral Subthalamic Nucleus Stimulation in Advanced Parkinson Disease. Arch Neurol 57: 983-988

Montaurier C, Morio B, Bannier S, Derost P, Arnaud P, Brandolini-Bunlon M, Giraudet C, Boirie Y, Durif F. 2007. Mechanisms of body weight gain in patients with Parkinson's disease after subthalamic stimulation. Brain: A Journal of Neurology 130(7): 1808-1818

Montel S, Bungener RC. 2009. Coping and quality of life of patients with Parkinson disease who have undergone deep brain stimulation of the subthalamic nucleus. Surgical Neurology 72(2): 105-111

Montel Sebastien, Bungener Catherine. 2008. What Relation Is There Between Deep Brain Stimulation and Coping Strategies in Parkinson's Disease?. Movement Disorders 23(12): 1780-1784

Moreau C, Defebvre L, Destee A, Bleuse S, Clement F, Blatt JL, Krystkowiak P, Devos D. 2008. STN-DBS frequency effects on freezing of gait in advanced Parkinson disease. Neurology 71: 80-84

Moretti R, Torre P, Antonello RM, Capus L, Marsala SZ, Cattaruzza T, Gazzato G, Bava A. 2003. Neuropsychological changes after subthalamic nucleus stimulation: a 12 month follow-up in nine patients with Parkinson's disease. Parkinsonism \& Related Disorders 10(2): 73-79

Moro E, Esselink RJ, Benabid AL, Pollak P. 2002. Response to levodopain parkinsonian patients with bilateral subthalamic nucleus stimulation. . Brain 125: 2408-17.

Moro E, Scerrati M, Romito LM, Roselli R, Tonali P, Albanese A. 1999. Chronic subthalamic nucleus stimulation reduces medication requirements in Parkinson's disease. Neurology 53(1):85-90.

Morrison CE, Borod JC, Perrine K, Beric A, Brin MF, Rezai A, Kelly P, Sterio D, Germano I, Weisz D, Olanow CW. 2004. Neuropsychological functioning following bilateral subthalamic nucleus stimulation in Parkinson's disease. Archives of Clinical Neuropsychology 19: 165-181

Muniz AM, Liu H, Lyons KE, Pahwa R, Liu W, Nobre FF, Nadal J. 2009. Comparison among probabilistic neural network, support vector machine and logistic regression for evaluating the effect of subthalamic stimulation in Parkinson disease on ground reaction force during gait. J Biomech 43(4): 720-6 
Novak KE, Nenonene EK, Bernstein LP, Vergenz S, Medalle G, Prager JM, Eller TW, Cozzens JW, Rezak M. 2006. Two cases of ischemia associated with subthalamic nucleus stimulator implantation for advanced Parkinson's disease. Mov Disord 21: 1477-83.

Novak P, Klemp JA, Ridings LW, Lyons KE, Pahwa R, Nazzaro JM. 2009. Effect of deep brain stimulation of the subthalamic nucleus upon the contralateral subthalamic nucleus in Parkinson disease. Neurosci Lett 463(1): 12-6

Novakova L, Ruzicka E, Jech R, Serranova T, Dusek P, Urgosik D. 2007. Increase in body weight is a nonmotor side effect of deep brain stimulation of the subthalamic nucleus in Parkinson's disease. Neuroendocrinology Letters 28(1): 21-25

Oh MY, Abosch A, Kim SH, Lang AE, Lozano AM. 2002. Long-termhardware-related complications of deep brain stimulation. Neurosurgery 50: 1268-76.

Okun MS, Fernandez HH, Wu SS, Kirsch-Darrow L, Bowers D, Bova F, Suelter M, Jacobson CE, Wang X, Gordon CW, Zeilman P, Romrell J, Martin P, Ward H, Rodriguez RL, Foote KD. 2009. Cognition and mood in Parkinson's disease in subthalamic nucleus versus globus pallidus interna deep brain stimulation: the COMPARE trial. Annals of Neurology 65(5): 586-95

Okun MS, Green J, Saben R, Gross R, Foote KD, Vitek JL. 2003. Mood changes with deep brain stimulation of STN and GPi: Results of a pilot study. Journal of Neurology, Neurosurgery \& Psychiatry 74(11): 15841586

Okun MS, Tagliati M, Pourfar M, Fernandez HH, Rodriguez RL, Alterman RL, Foote KD. 2005. Management of referred deep brain stimulation failures: A retrospective analysis from 2 Movement Disorders Centers. Archives of Neurology Arch. Neurol. 62(8): 1250-1255

Ory-Magne F, Brefel-Courbon C, Simonetta-Moreau M, Fabre N, Lotterie JA, Chaynes P, Berry I, Lazorthes Y, Rascol O. 2007. Does ageing influence deep brain stimulation outcomes in Parkinson's disease?. Movement Disorders 22(10): 1457-1463

Østergaard K, Sunde N, Dupont E. 2002. Effects of Bilateral Stimulation of the Subthalamic Nucleus in Patients with Severe Parkinson's Disease and Motor Fluctuations. Movement Disorders 17(4): 693-700

Østergaard K, Sunde NA. 2006. Evolution of Parkinson's Disease During 4 Years of Bilateral Deep Brain Stimulation of the Subthalamic Nucleus. Movement Disorders 21(5): 624-631

O'Sullivan D, Pell M. 2009. Long-term follow-up of DBS of thalamus for tremor and STN for Parkinson's disease. Brain Research Bulletin 78(2-3): 119-121

Pahwa R, Wilkinson SB, Overman J, Lyons KE. 2003. Bilateral subthalamic stimulation in patients with Parkinson disease: long-term follow up. Journal of Neurosurgery 99(1): 71-77

Paluzzi A, Belli A, Bain P, Liu X, Aziz TM. . 2006. Operative and hardware complications of deep brain stimulation for movement disorders. Br J Neurosurg 20: 290-95.

Panikar D, Kishore A. 2003. Deep brain stimulation for Parkinson's disease. Neurology India 51(2): 167-75

Patel NK, Plaha P, O’Sullivan K, McCarter R, Heywood P, Gill SS. 2003. MRI directed bilateral stimulation of the subthalamic nucleus in patients with Parkinson's disease. J Neurol Neurosurg Psychiatry 74: 16311637

Peppe A, Pierantozzi M, Bassi A, Altibrandi MG, Brusa L, Stefani A, Stanzione P, Mazzone P. 2004. Stimulation of the subthalamic nucleus compared with the globus pallidus internus in patients with Parkinson disease. J Neurosurg 101: 195-200

Peron J, Biseul I, Leray E, Le jeune F, Drapier D, Vicente S, Drapier S, Sauleau P, Haegelen C, Vérin M. 2009. Subthalamic nucleus stimulation affects fear and sadness recognition in Parkinson's disease. Neuropsychology 24(1): 1-8 (ePub 2009)

Péron J, Grandjean D, Le Jeune F, Sauleau P, Haegelen C, Drapier D, Rouaud T, Drapier S, Vérin M. 2009. Recognition of emotional prosody is altered after subthalamic nucleus deep brain stimulation in Parkinson's disease. Neuropsychologia 48(4): 1053-1062. Epub 2009

Perozzo PM, Rizzone M, Bergamasco B, Castelli L, Lanotte M, Tavella A, Torre E, Lopiano L. 2001. Deep brain stimulation of the subthalamic nucleus in Parkinson's disease: comparison of pre- and postoperative neuropsychological evaluation. Journal of the Neurological Sciences 192: 9-15

Perozzo PM, Rizzone M, Bergamasco B, Castelli L, Lanotte M, Tavella A, Torre E, Lopiano L. 2001. Deep brain stimulation of subthalamicus nucleus: behavioral modifications and familiar relations. Neurol Sci 22: 81-82

Perriol M-P, Krystkowiak P, Defebvre L, Blond S, Destee A, Dujardin K. 2006. Stimulation of the subthalamic nucleus in Parkinson's disease: Cognitive and affective changes are not linked to the motor outcome. Parkinsonism and Related Disorders 12: 205-210

Piboolnurak P, Lang AE, Lozano AM, Miyasaki JM, Saint-Cyr JA, Poon Y-Y, Hutchison WD, Dostrovsky JO, Moro E. 2007. Levodopa Response in Long-Term Bilateral Subthalamic Stimulation for Parkinson's Disease. Movement Disorders 22(7): 990-997

Pilitsis JG, Rezai AR, Boulis NM, Henderson JM, Busch RM, Kubu CS. 2005. A preliminary study of transient confusional states following bilateral subthalamic stimulation for Parkinson's disease. Stereotactic and Functional Neurosurgery 83(2-3): 67-70 
Pillon B, Ardouin C, Damier P, Krack P, Houeto JL, Klinger H, Bonnet AM, Pollak P, Benabid AL, Agid Y. 2000. Neuropsychological changes between "off” and “on” STN or GPi stimulation in Parkinson's disease. Neurology 55: 411-418

Pinter MM, Alesch F, Murg M, Seiwald M, Helscher RJ, Binder H. 1999. Deep brain stimulation of the subthalamic nucleus for control of extrapyramidal features in advanced idiopathic parkinson's disease: one year follow-up. J Neural Transm 106(7-8):693-709.

Pinto S, Gentil M, Fraix V, Benabid AL, Pollak P. 2003. Bilateral subthalamic stimulation effects on oral force control in Parkinson's disease. J Neurol 250(2): 179-87.

Pinto S, Thobois S, Costes N, Le Bars D, Benabid A-L, Broussolle E, Pollak P, Gentil M. 2004. Subthalamic nucleus stimulation and dysarthria in Parkinson's disease: a PET study. Brain 127: 602-615

Plaha P, Ben-Shlomo Y, Patel NK, Gill SS. 2006. Stimulation of the caudal zona incerta is superior to stimulation of the subthalamic nucleus in improving contralateral parkinsonism. Brain 129: 1732-1747

Pollak P, Fraix V, Krack P, Moro E, Mendes A, Chabardes S, Koudsie A, Benabid A-L. 2002. Treatment results: Parkinson's disease. Movement Disorders 17 supp 3 S75-S83

Porat O, Cohen OS, Schwartz R, Hassin-Baer S. . 2009. Association of preoperative symptom profile with psychiatric symptoms following subthalamic nucleus stimulation in patients with Parkinson's disease. J Neuropsychiatry Clin Neurosci 21(4): 398-405

Portman AT, van Laar T, Staal MJ, Rutgers AWF, Journee HL, Leenders KL. 2006. Chronic stimulation of the subthalamic nucleus increases daily on-time without dyskinesia in advanced Parkinson's disease. Parkinsonism and Related Disorders 12: 143-148

Pützer M, Barry WJ, Moringlane JR, Fuss G, Spiegel J, Dillmann U, Sittinger H. 2003. Effect of deep brain stimulation on glottal phonation in patients with Parkinson's disease and multiple sclerosis. Folia Phoniatrica et Logopedica 55(5): 220-32

Ray NJ, Jenkinson N, Brittain J, Holland P, Joint C, Nandi D, Bain PG, Yousif N, Green A, Stein JS, Aziz TZ. 2009. The role of the subthalamic nucleus in response inhibition: evidence from deep brain stimulation for Parkinson's disease. Neuropsychologia 47(13): 2828-34. Epub 2009

Rivaud-Péchoux S, Vermersch A-I, Gaymard B, Ploner CJ, Bejjani BP, Damier P, Demeret S, Agid Y, PierrotDeseilligny C. 2000. Improvement of memory guided saccades in parkinsonian patients by high frequency subthalamic nucleus stimulation. J Neurol Neurosurg Psychiatry 68: 381-384

Rizzone M, Ferrarin M, Pedotti A, Bergamasco B, Bosticco E, Lanotte M, Perozzo P, Tavella A, Torre E, Recalcati M, Melcarne A, Lopiano L. 2002. High-frequency electrical stimulation of the subthalamic nucleus in Parkinson's disease: kinetic and kinematic gait analysis. Neurol Sci 23: S103-S104

Robertson LT, Horak FB, Anderson VC, Burchiel KJ, Hammerstad JP. 2001. Assessments of Axial Motor Control during Deep Brain Stimulation in Parkinsonian Patients. Neurosurgery 48(3): 544-552

Rodriguez-Oroz MC, Obeso JA, Lang AE, Houeto JL, Pollak P, Rehncrona S, Kulisevsky J, Albanese A, Volkmann J, Hariz MI, Quinn NP, Speelman JD, Guridi J, Zamarbide I, Gironell A, Molet J, PascualSedano B, Pidoux B, Bonnet AM, Agid Y, Xie J, Benabid A-L, Lozano AM, Saint-Cyr J, Romito L, Contarino MF, Scerrati M, Fraix V, Van Blercom N. 2005. Bilateral deep brain stimulation in Parkinson's disease: A multicentre study with 4 years follow-up. Brain: A Journal of Neurology 128(10): 2240-2249

Rodriguez-Oroz MC, Zamarbide I, Guridi J, Palmero MR, Obeso JA. 2004. Efficacy of deep brain stimulation of the subthalamic nucleus in Parkinson's disease 4 years after surgery: double blind and open label evaluation. J Neurol Neurosurg Psychiatry 75: 1382-1385.

Romito L, Scerrati M, Contarino MF, Bentivoglio AR, Tonali P, Albanese A. 2002. Long-term follow up of subthalamic nucleus stimulation in Parkinson's disease. Neurology 58(10): 1546-1550

Romito LM, Contarino FM, Albanese A. 2009. Transient gender-related effects in Parkinson's disease patients with subthalamic stimulation. J Neurol 257(4): 603-8. Epub 2009

Romito LMA, Contarino MF, Ghezzi D, Franzini A, Garavaglia B, Albanese A. 2005. High frequency stimulation of the subthalamic nucleus is efficacious in Parkin disease. Journal of Neurology 252(2): 208211

Rothlind JC, Cockshott RW, Starr PA, Marks WJ Jr. 2007. Neuropsychological performance following staged bilateral pallidalor subthalamic nucleus deep brain stimulation for Parkinson'sdisease. . J Int Neuropsychol Soc 13: 68-79.

Rousseaux M, Krystkowiak P, Kozlowski O, Özsancak C, Blond S, Destée A. 2004. Effects of subthalamic nucleus stimulation on parkinsonian dysarthria and speech intelligibility. J Neurol 251: 327-334

Sailer A, Cunic DI, Paradiso GO, Gunraj CA, Wagle-Shukla A, Moro E, Lozano AM, Lang AE, Chen R. 2007. Subthalamic nucleus stimulation modulates afferent inhibition in Parkinson disease. Neurology 68(5): 356-363.

Saint-Cyr JA, Trépanier LL, Kumar R, Lozano AM, Lang AE. 2000. Neuropsychological consequences of chronic bilateral stimulation of the subthalamic nucleus in Parkinson's disease. Brain 123 2091-2108

Samii A, Kelly VE, Slimp JC, Shumway-Cook A, Goodkin R. . 2007. Staged unilateral versus bilateral subthalamic nucleus stimulator implantation in Parkinson disease. . Mov Disord 22: 1476-81. 
Santens P, De Letter M, Van Borsel J, De Reuck J, Caemaert J. 2003. Lateralized effects of subthalamic nucleus stimulation on different aspects of speech in Parkinson s disease. Brain and Language 87: 253-258

Sauleau P, Leray E, Rouaud T, Drapier S, Drapier D, Blanchard S, Drillet G, Péron J, Vérin M. 2009. Comparison of weight gain and energy intake after subthalamic versus pallidal stimulation in Parkinson's disease. Mov Disord 24(14): 2149-55.

Sauleau P, Raoul S, Lallement F, Rivier I, Drapier S, Lajat Y, Verin M. 2005. Motor and non motor effects during intraoperative subthalamic stimulation for Parkinson's disease. J Neurol 252(4):457-64

Schadt CR, Cox KL, Tramontana MG, Byrne DW, Davis TL, Fang JY, Konrad PE, Padaliya B, Mutter RW, Gill CE, Richardson CR, Charles PD. 2006. Depression and Intelligence in Patients with Parkinson's Disease and Deep-Brain Stimulation. Journal of the National Medical Association 98(7): 1121-1125

Schneider F, Habel U, Volkmann J, Regel S, Kornischka J, Sturm V, Freund HJ . 2003. Deep brain stimulation of the subthalamic nucleus enhances emotional processing in Parkinson disease. Archives of General Psychiatry 60(3): 296-302

Schoenberg MR, Mash KM, Bharucha KJ, Francel PC, Scott JG. 2008. Deep Brain Stimulation Parameters Associated with Neuropsychological Changes in Subthalamic Nucleus Stimulation for Refractory Parkinson's Disease. Stereotact Funct Neurosurg 86: 337-344

Schroeder U, Kuehler A, Haslinger B, Erhard P, Fogel W, Tronnier VM, Lange KM, Boeckner H, CeballosBaumann AO. 2002. Subthalamic nucleus stimulation affects striato-anterior cingulate cortex circuit in a response vonflict task: a PET study. Brain 125: 1995-2004

Schroeder U, Kuehler A, Hennenlotter A, Haslinger B, Tronnier VM, Krause M, Pfister R, Sprengelmeyer R, Lange KW, Ceballos-Baumann AO. 2004. Facial expression recognition and subthalamic nucleus stimulation. J Neurol Neurosurg Psychiatry 75: 648-650.

Schroeder U, Kuehler A, Lange KW, Haslinger B, Tronnier VM, Krause M, Pfister R, Boecker H, CeballosBaumann AO. 2003. Subthalamic Nucleus Stimulation Affects a Frontotemporal Network: A PET Study. Annals of Neurology 54(4): 445-450

Schüpbach M, Gargiulo M, Welter ML, Mallet L, Behar C, Houeto JL, Maltete D, Mesnage V, Agid Y. 2006. Neurosurgery in Parkinson disease. A distressed mind in a repaired body? Neurology 66:1811-1816

Schüpbach MWM, Welter ML, Bonnet AM, Elbaz A, Grossardt BR, Mesnage V, Houeto JL, Maltête D, Mallet L, Rocca WA, Mallet A, Agid Y. 2007. Mortality in patients with Parkinson's disease treated by stimulation of the subthalamic nucleus. Movement Disorders 22(2): 257-261

Schüpbach WM, Maltête D, Houeto JL, Tezenas du Montcel S, Mallet L, Welter ML, Gargiulo M, Béhar C, Bonnet AM, Czernecki V, Pidoux B, Navarro S, Dormont D, Cornu P, Agid Y. 2007. Neurosurgery at an earlier stage of Parkinson disease: a randomized, controlled trial . Neurology 68(4): 267-71

Schüpbach WMM, Chastan N, Welter ML, Houeto JL, Mesnage V, Bonnet AM, Czernecki V, Maltete D, Hartmann A, Mallet L, Pidoux B, Dormont D, Navarro S, Cornu P, Mallet A, Agid Y. 2005. Stimulation of the subthalamic nucleus in Parkinson's disease: A 5 year follow up. Journal of Neurology, Neurosurgery \& Psychiatry 76(12): 1640-1644

Scotto di Luzio AE, Ammannati F, Marini P, Sorbi S, Mennonna P. 2001. Which target for DBS in Parkinson's disease? Subthalamic nucleus versus globus pallidus internus. Neurol Sci 22: 87-88

Seif C, Herzog J, van der Horst C, Schrader B, Volkmann J, Deuschl G, Juenemann K-P, Braun PM. 2004. Effect of subthalamic deep brain stimulation on the function of the urinary bladder. . Ann Neurol 55: 11820.

Seijo FJ, Alvarez-Vega MA, Gutierrez JC, Fdez-Glez F, Lozano B. 2007. Complications in subthalamic nucleus stimulation surgery fortreatment of Parkinson's disease. Review of 272 procedures. Acta Neurochir (Wien) 149: 867-75.

Siderowf A, Jaggi JL, Xie SX, Loveland-Jones C, Leng L, Hurtig H, Colcher A, Stern M, Chou KL, Liang G, Maccarone H, Simuni T, Baltuch G. 2006. Long-Term Effects of Bilateral Subthalamic Nucleus Stimulation on Health-Related Quality of Life in Advanced Parkinson's Disease. Movement Disorders 21(6): 746-753

Sillay KA, Larson PS, Starr PA. 2008. Deep brain stimulator hardware-related infections: incidence and management in a large series. Neurosurgery 62: 360-67

Simonin C, Tir M, Devos D, Kreisler A, Dujardin K, Salleron J, Delval A, Blond S, Defebvre L, Destée A, Krystkowiak P. 2009. Reduced levodopa-induced complications after 5 years of subthalamic stimulation in Parkinson's disease: a second honeymoon. J Neurol 256(10): 1736-41

Simuni T, Jaggi JL, Mulholland H, Hurtig HI, Colcher A, Siderof AD, Ravina B, Skolnick BE, Goldstein R, Stern MB, Baltuch GH. 2002. Bilateral stimulation of the subthalamic nucleus in patients with Parkinson disease: a study of efficacy and safety. J Neurosurg 96: 666-672

Slowinski JL, Putzke JD, Uitti RJ, Lucas JA, Turk MF, Kall BA, Wharen RE. 2007. Unilateral deep brain stimulation of the subthalamic nucleus for Parkinson disease. Journal of Neurosurgery 106(4): 626-632

Smeding HM, Esselink RA, Schmand B, Koning-Haanstra M, Nijhuis I, Wijnalda EM, Speelman JD. 2005. Unilateral pallidotomy versus bilateral subthalamic nucleus stimulation in PD-a comparison of neuropsychological effects. Journal of Neurology 252(2): 176-82 
Smeding HMM, Speelman JD, Koning-Haanstra M, Schuurman PR, Nijssen P, van Laar T, Schmand B. 2006. Neuropsychological effects of bilateral STN stimulation in Parkinson disease. A controlled study. Neurology 66: 1830-1836

Soulas T, Gurruchaga J-M, Palfi S, Cesaro P, Nguyen J-P, Fenelon G. 2008. Attempted and completed suicides after subthalamic nucleus stimulation for Parkinson's disease. J Neurol Neurosurg Psychiatry 79: 952-954

Spottke EA, Volkmann J, Lorenz D, Krack P, Smala AM, Sturm V, Gerstner A, Berger K, Hellwig D, Deuschl G, Freund HJ, Oertel WH, Dodel RC. 2002. Evaluation of healthcare utilization and health status of patients with Parkinson's disease treated with deep brain stimulation of the subthalamic nucleus. J Neurol 249: 759-766

Starr PA, Christine CW, Theodospoulos PV, Lindsey N, Byrd D, Mosley A, Marks Jr. WJ. 2002. Implantation of deep brain stimulators into the subthalamic nucleus: technical approach and magnetic resonance imagingverified lead locations. J Neurosurg 97: 370-387

Stefani A, Lozano AM, Peppe A, Stanzione P, Galati S, Tropepi D, Pierantozzi M, Brusa L, Scarnati E, Mazzone P. 2007. Bilateral deep brainstimulation of the pedunculopontine and subthalamic nuclei insevere Parkinson's disease. Brain 130: 1596-607.

Stolze H, Klebe S, Poepping M, Lorenz D, Herzog J, Hamel W, Schrader B, Raethjen J, Wenzelburger R, Mehdorn HM, Deuschl G, Krack P. 2001. Effects of bilateral subthalamic nucleus stimulation on parkinsonian gait. Neurology 57: 144-146

Tabbal SD, Revilla FJ, Mink JW, Schneider-Gibson P, Wernle AR, de Erausquin GA, Permutter JS, Rich KM, Dowling JL. 2007. Safety and efficacy of subthalamic nucleus deep brain stimulation performed with limited intraoperative mapping for treatment of Parkinson's disease. Neurosurgery 61(3): 119-127

Tabbal SD, Ushe M, Mink JW, Revilla FJ, Wernle AR, Homg M, Karimi M, Perlmutter JS. 2008. Unilateral subthalamic nucleus stimulation has a measurable ipsilateral effect on rigidity and bradykinesia in parkinson disease. Experimental Neurology 211: 234-242

Tamma F, Rampini P, Egidi M, Caputo E, Locatelli M, Pesenti A, Chiesa V, Ardolino G, Foffani G, Meda B, Pellegrini M, Priori A. 2003. Deep brain stimulation for Parkinson's disease: The experience of the Policlinico-San Paolo Group in Milan. Neurological Sciences 24(Suppl1): S41-S42

Tanei T, Kajita Y, Kaneoko Y, Takebayashi S, Nakatsubo D, Wakabayashi T. 2009. Staged bilateral deep brain stimulation of the subthalamic nucleus for the treatment of Parkinson's disease. Acta Neurochirurgica 151(6): 589-594.

Tanei T, Kajita Y, Nihashi T, Kaneoke Y, Takebayashi S, Nakatsubo D, Wakabayashi T. 2009. Changes in regional blood flow induced by unilateral subthalamic nucleus stimulation in patients with Parkinson's disease. Neurol Med Chir (Tokyo) 49(11): 507-13.

Tassorelli C, Buscone S, Sandrini G, Pacchetti C, Furnari A, Zangaglia R, Bartolo M, Nappi G, Martignoni E. 2009. The role of rehabilitation in deep brain stimulation of the subthalamic nucleus for Parkinson's disease: a pilot study. Parkinsonism Relat Disord 15(9): 675-81

Tavella A, Bergamasco B, Bosticco E, Lanotte M, Perozzo P, Rizzone M, Torre E, Lopiano L. 2002. Deep brain stimulation of the subthalamic nucleus in Parkinson's disease: long-term follow-up. Neurol Sci 23: S111S112

Temel Y, Ackermans L, Celik H, Spincemaille GH, van der Linden C, Walenkamp GH, van de Kar T, VisserVandewalle V. 2004. Management of hardwareinfections following deep brain stimulation. . Acta Neurochir (Wien) 146: 355-61.

Temperli P, Ghika J, Villemure JG, Burkhard PR, Bogousslavsky J, Vingerhoets FJ. 2003. How do parkinsonian signs return after discontinuation of subthalamic DBS?. Neurology 60(1): 78-81

Thobois S, Mertens P, Guenot M, Hermier M, Mollion H, Bouvard M, Chazot G, Broussolle E, Sindou M. 2002. Subthalamic nucleus stimulation in Parkinson's disease. Clinical evaluation of 18 patients. J Neurol 249: 529-534

Tir M, Devos D, Blond S, Touzet G, Reyns N, Duhamel A, Cottencrin O, Dujardin K, Cassim F, Destée A, Defebvre L, Krystkowiak P. 2007. Exhaustive, one-year follow-up of subthalamic nucleus deep brain stimulation in a large, single-center cohort of Parkinsonian patients. Neurosurgery 61(2): 297-304.

Tomaszewski KJ, Holloway RG. 2001. Deep brain stimulation in the treatment of Parkinson's disease: a costeffectiveness analysis. Neurology 57(4): 663-71

Tommasi G, Krack P, Fraix V, Le Bas J-F, Chabardes S, Benabid A-L, Pollak P. 2008. Pyramidal tract side effects induced by deep brain stimulation of the subthalamic nucleus. J Neurol Neurosurg Psychiatry 79: 813-819

Törnqvist AL, Schalén L, Rehncrona S. 2005. Effects of different electrical parameter settings on the intelligibility of speech in patients with Parkinson's disease treated with subthalamic deep brain stimulation. Movement Disorders 20(4): 416-423

Trachani E, Constantoyannis C, Sirrou V, Kefalopoulou Z, Markaki E, Chroni E. 2009. Effects of subthalamic nucleus deep brain stimulation on sweating function in Parkinson's disease. Clin Neurol Neurosurg 112(3): 213-7. Epub 2009 
Trepanier LL, Kumar R, Lozano AM, Lang AE, Saint-Cyr JA. 2000. Neuropsychological Outcome of GPi Pallidotomy and GPi or STN Deep Brain Stimulation in Parkinson's Disease. Brain and Cognition 42, 324-347

Tripoliti E, Zrinzo L, Martinez-Torres I, Tisch S, Frost E, Borrell E, Hariz MI, Limousin P. 2008. Effects of contact location and voltage amplitude on speech and movement in bilateral subthalamic nucleus deep brain stimulation. Movement Disorders 23(16): 2377-2383

Tronnier VM, Krause M, Heck A, Kronenbürger M, Bonsnato MM, Tronnier J, Fogel W. 1999. Deep brain stimulation for the treatment of movement disorders. Neurology Psychiatry and Brain Research 6(4): 199212

Tröster AI, Fields JA, Wilkinson S, Pahwa R, Koller WC, Lyons KE. 2003. Effect of motor improvement on quality of life following subthalamic stimulation is mediated by changes in depressive symptomatology. Stereotactic and Functional Neurosurgery 80(1-4): 43-47

Tsai ST, Lin SH, Lin S-Z, Chen J-Y, Lee C-W, Chen S-Y. 2007. Neuropsychological effects after chronic subthalamic stimulation and the topography of the nucleus in Parkinson's disease. Neurosurgery 61(5): 1024-1029

Umemura A, Jaggi JL, Hurtig HI, Siderowf AD, Colcher A, Stern MB, Baltuch GH. 2003. Deep brain stimulation for movement disorders: morbidity and mortality in 109 patients. Journal of Neurosurgery 98(4): 779-784

Valldeoriola F, Morsi O, Tolosa E, Rumià J, Martí MJ, Martínez-Martín P. 2007. Prospective comparative study on cost-effectiveness of subthalamic stimulation and best medical treatment in advanced Parkinson's disease. Mov Disord 22(15): 2183-91

Valldeoriola F, Pilleri M, Tolosa E, Molinuevo JL, Rumià J, Ferrer E. 2002. Bilateral Subthalamic Stimulation Monotherapy in Advanced Parkinson's Disease: Long-Term Follow-Up of Patients. Movement Disorders 17(1): $125-132$

Varma TRK, Fox SH, Eldrige PR, Littlechild P, Byrne P, Forster A, Marshall A, Cameron H, McIver K, Fletcher N, Steiger M. 2003. Deep brain stimulation of the subthalamic nucleus: effectiveness in advanced Parkinson's disease patients previously reliant on apomorphine. Journal of Neurology Neurosurgery and Psychiatry 74(2): 170-174

Vesper J, Haak S, Ostertag C, Nikkhah G. 2007. Subthalamic nucleus deep brain stimulation in elderly patients Analysis of outcome and complications. BMC Neurology BMC Neurol. 7

Vesper J, Klostermann F, Stockhammer F, Funk Th, Brock M. 2002. Results of chronic subthalamic nucleus stimulation for Parkinson's disease: a 1-year follow-up study. Surg Neurol 57: 306 -313.

Vicente S, Biseul I, Péron J, Philippot P, Drapier S, Drapier D, Sauleau P, Haegelen C, Vérin M. 2009. Subthalamic nucleus stimulation affects subjective emotional experience in Parkinson's disease patients. Neuropsychologia 47(8-9): 1928-1937

Vingerhoets FJG, Villemure J-G, Temperli P, Pollo C, Pralong E, Ghika J. 2002. Subthalamic DBS replaces levodopa in Parkinson's disease. Two-year follow-up. Neurology 58:396-401

Visser-Vandewalle V, van der Linden C, Temel Y, Celik H, Ackermans L, Spincemaille G, Caemaert J. 2005. Long-term effects of bilateral subthalamic nucleus stimulation in advanced Parkinson disease: A four year follow-up study. Parkinsonism \& Related Disorders 11(3): 157-165

Voges J, Hilker R, Bötzel K, Kiening KL, Kloss M, Kupsch A, Schnitzler A, Schneider GH, Steude U, Deuschl G, Pinsker MO. 2007. Thirty days complication rate following surgery performed for deep-brainstimulation. Mov Disord 22(10):1486-9.

Voges J, Waerzeggers Y, Maarouf M, Lehrke R, Koulousakis A, Lenartz D, Sturm V. 2006. Deep-brain stimulation:long-term analysis of complications caused by hardware andsurgery experiences from a single centre. J Neurol Neurosurg Psychiatry 77: 868-72.

Volkmann J, Albanese A, Kulisevsky J, Tornqvist A-L, Houeto J-L, Pidoux B, Bonnet A-M, Mendes A, Benabid A-L, Fraix V, Van Blercom N, Xie J, Obeso J, Rodriguez-Oroz MC, Guridi J, Schnitzler A, Timmermann I, Gironell AA, Molet J, Pascual-Sedano B, Rehncrona SI, Moro E, Lang AC, Lozano AM, Bentivoglio AR, Scerrati M, Contarino MF, Romito L, Janssens M, Agid Y. 2009. Long-Term Effects of Pallidal or Subthalamic Deep Brain Stimulation on Quality of Life in Parkinson's Disease. Movement Disorders 24(8): 1154-1161

Volkmann J, Allert N, Voges J, Weiss PH, Freund HJ, Sturm V. 2001. Safety and efficacy of pallidal or subthalamic nucleus stimulation in advanced PD. Neurology 56(4): 548-51

Voon V, Krack P, Lang AE, Lozano AM, Dujardin K, Schupbach M, D’Ambrosia J, Thobois S, Tamma F, Herzog J, Speelman JD, Samanta J, Kubu C, Rossignol H, Poon Y-Y, Saint-Cyr JA, Ardouin C, Moro E. 2008. A multicentre study on suicide outcomes following subthalamic stimulation for Parkinson's disease. Brain 131: 2720-2728

Voon V, Saint-Cyr J, Lozano AM, Moro E, Poon YY, Lang AE. 2005. Psychiatric symptoms in patients with Parkinson disease presenting for deep brain stimulation surgery. Journal of Neurosurgery 103: 246-251

Walker HC, Lyerly M, Cutter G, Hagood J, Stover NP, Guthrie SL, Guthrie BL, Watts RL. 2009. Weight changes associated with unilateral STN DBS and advanced PD. Parkinsonism Relat Disord 15(9): 709-11 
Walker HC, Watts RL, Guthrie S, Wang D, Guthrie BL. 2009. Bilateral effects of unilateral subthalamic deep brain stimulation on Parkinson's disease at 1 year. Neurosurgery 65(2): 302-9

Wang J, Ma Y, Huang Z, Sun B, Guan Y, Zuo C. 2009. Modulation of metabolic brain function by bilateral subthalamic nucleus stimulation in the treatment of Parkinson's disease. J Neurol 257(1): 72-8. Epub 2009

Wang X, Chang C, Geng N, Li N, Wang J, Ma J, Xue W, Zhao W, Wu H, Wang P, Gao G. 2009. Long-term effects of bilateral deep brain stimulation of the subthalamic nucleus on depression in patients with Parkinson's disease. Parkinsonism Relat Disord 15(8): 587-91

Weaver FM, Follett K, Stern M, Hur K, Harris C, Marks WJ, Rothlind J, Sagher O, Reda D, Moy CS, Pahwa R, Burchiel K, Hogarth P, Lai EC, Duda JE, Holloway K, Samii A, Horn S, Bronstein J, Stoner G, Heemskerk J, Huang GD. 2009. Bilateral deep brain stimulation vs best medical therapy for patients with advanced Parkinson disease: a randomized controlled trial. Journal of the American Medical Association 301(1): 63-73

Welter ML, Houeto JL, Tezenas du Montcel S, Mesnage V, Bonnet AM, Pillon B, Arnulf I, Pidoux B, Dormont D, Cornu P, Agid Y. 2002. Clinical predictive factors of subthalamic stimulation in Parkinson's disease. Brain 125: 575-583

Whelan BM, Murdoch BE, Theodoros DG, Hall B, Silburn P. 2003. Defining a role for the subthalamic nucleus within operative theoretical models of subcortical participation in language. J Neurol Neurosurg Psychiatry 74(11):1543-50

Wider C, Pollo C, Bloch J, Burkhard PR, Vingerhoets FJ. 2008. Long-term outcome of 50 consecutive Parkinson's disease patients treated with subthalamic deep brain stimulation. Parkinsonism Relat Disord. 14(2): 114-9

Winge K, Nielsen KK, Stimpel H, Lokkegaard A, Jensen SR, Werdelin L. 2007. Lower urinary tract symptoms and bladder control in advanced Parkinson's disease: effects of deep brain stimulation in the subthalamic nucleus. Mov Disord 22(2): 220-5

Witjas T, Kaphan E, Régis J, Jouve E, Chérif AA, Péragut J-C, Azulay JP. 2007. Effects of chronic subthalamic stimulation on nonmotor fluctuations in Parkinson's disease. Movement Disorders 22(12): 1729-1734

Witt K, Daniels C, Herzog J, Lorenz D, Volkmann J, Reiff J, Mehdorn M, Deuschl G, Krack P. 2006. Differential Effects of L-Dopa and Subthalamic Stimulation on Depressive Symptoms and Hedonic Tone in Parkinson's Disease. The Journal of Neuropsychiatry and Clinical Neurosciences 18: 397-401

Witt K, Daniels C, Reiff J, Krack P, Volkmann J, Pinsker MO, Krause M, Tronnier V, Kloss M, Schnitzler A, Wojtecki L, Bötzel K, Danek A, Hilker R, Sturm V, Kupsch A, Karner E, Deuschl G. 2008. Neuropsychological and psychiatric changes after deep brain stimulation for Parkinson's disease: a randomised, multicentre study. Lancet Neurol 7: 605-14

Witt K, Pulkowski U, Herzog J, Lorenz D, Hamel W, Deuschl G, Krack P. 2004. Deep Brain Stimulation of the Subthalamic Nucleus Improves Cognitive Flexibility but Impairs Response Inhibition in Parkinson Disease. Arch Neurol 61: 697-700

Wojtecki L, Timmermann L, Jorgens S, Sudmeyer M, Maarouf M, Treuer H, Gross J, Lehrke R, Koulousakis A, Voges J, Sturm V, Schnitzler A. 2006. Frequency-Dependent Reciprocal Modulation of Verbal Fluency and Motor Functions in Subthalamic Deep Brain Stimulation. Arch Neurol 63: 1273-1276

Xiaowu H, Xiufeng J, Xiaoping Z, Bin H, Laixing W, Yiqun C, Jinchuan L, Aiguo J, Jianmin L. 2009. Risks of intracranial hemorrhage in patients with Parkinson's disease receiving deep brain stimulation and ablation. Parkinsonism Relat Disord 16(2): 96-100. Epub 2009 Aug 13.

Xie J, Krack P, Benabid AL, Pollak P. 2001. Eff ect of bilateral subthalamicnucleus stimulation on parkinsonian gait. . J Neurol 248: 1068-72

Yamada K, Hamasaki T, Kuratsu J. 2009. Subthalamic nucleus stimulation applied in the earlier vs. advanced stage of Parkinson's disease - retrospective evaluation of postoperative independence in pursuing daily activities. Parkinsonism Relat Disord 15(10): 746-51

Yokoyama T, Sugiyama K, Nishizawa S, Yokota N, Ohta S, Uemura K. 1999. Subthalamic Nucleus Stimulation for Gait Disturbance in Parkinson's Disease. Neurosurgery Volume 45(1), July 1999, p 41

York MK, Dulay M, Macias A, Levin HS, Grossman R, Simpson R, Jankovic J. 2008. Cognitive declines following bilateral subthalamic nucleus deep brain stimulation for the treatment of Parkinson's disease. J Neurol Neurosurg Psychiatry 79: 789-795

York MK, Wilde EA, Simpson R, Jankovic J. 2009. Relationship between neuropsychological outcome and DBS surgical trajectory and electrode location. J Neurol Sci 287(1-2):159-71

Yoshida F, Miyagi Y, Kishimoto J, Morioka T, Murakami N, Hashiguchi K, Samura K, Sakae N, Yamasaki R, Kawaguchi M, Sasaki T. 2009. Subthalamic Nucleus Stimulation Does Not Cause Deterioration of Preexisting Hallucinations in Parkinson's Disease Patients. Stereotactic and Functional Neurosurgery 87(1): 45-49

Zahodne Laura B, Okun Michael S, Foote Kelly D, Fernandez Hubert H, Rodriguez Ramon L, Kirsch-Darrow Lindsey, Bowers Dawn. 2009. Cognitive decline one year after unilateral deeo brain stimulation surgery in Parkinson's disease: A controlled Study using reliable change. The Clinical Neuropsychologist, 23: 385405 
Zahodne LB, Okun MS, Foote KD, Fernandez HH, Rodriguez RL, Wu SS, Kirsch-Darrow I, Jacobson IV CE, RosadCo, Bowers D. 2009. Greater improvement in quality of life following unilateral deep brain stimulation surgery in the globus pallidus as compared to the subthalamic nucleus. Journal of Neurology 256(8): 1321-1329

Zangaglia R, Pacchetti C, Pasotti C, Mancini F, Servello D, Sinforiani E, Cristina S, Sassi M, Nappi G. 2009. Deep brain stimulation and cognitive functions in Parkinson's disease: A three-year controlled study. Mov Disord 24(11):1621-8.

Zanini S, Melatini A, Capus L, Gioulis M, Vassallo A, Bava A. 2003. Language recovery following subthalamic nucleus stimulation in Parkinson's disease. NeuroReport $14: 511-516$

Zanini S, Moschella V, Stefani A, Peppe A, Pierantozzi M, Galati S, Costa A, Mazzone P, Stanzione P. 2009. Grammar improvement following deep brain stimulation of the subthalamic and the pedunculopontine nuclei in advanced Parkinson's disease: a pilot study. Parkinsonism Relat Disord 15(8): 606-9

Zhang JG, Zhang K, Ma Y, Hu WH, Yang AC, Chu JS, Wu ST, Ge M, Zhang Y, Wang ZC. 2006. Follow-up of bilateral subthalamic deep brain stimulation for Parkinson's disease. Acta Neurochir Suppl 99: 43-47

Zheng Z, Li Y, Li J, Zhang Y, Zhang X, Zhuang P. 2009. Stimulation-induced dyskinesia in the early stage after subthalamic deep brain stimulation. Stereotact Funct Neurosurg 88(1):29-34. Epub 2009

Zibetti M, Pesare M, Cinquepalmi A, Rosso M, Castelli L, Rizzi L, Bergamasco B, Lanotte M, Lopiano L. 2009. Neuro-psychiatric therapy during chronic subthalamic stimulation in Parkinson's disease. Parkinsonism \& Related Disorders 15(2): 128-133

Zibetti M, Torre E, Cinquepalmi A, Rosso M, Ducati A, Bergamasco B, Lanotte M, Lopiano L. 2007. Motor and nonmotor symptom follow-up in Parkinsonian patients after deep brain stimulation of the subthalamic nucleus. European Neurology 58(4): 218-223 